\title{
Environmental Degradation by Invasive Alien Plants in the Anthropocene: Challenges and Prospects for Sustainable Restoration
}

\author{
Prabhat Kumar Rai ${ }^{1}$ D
}

Received: 20 July 2021 / Revised: 19 August 2021 / Accepted: 20 August 2021 / Published online: 10 September 2021

(c) The Author(s), under exclusive license to Springer Nature Singapore Pte Ltd. 2021

\begin{abstract}
Biodiversity, soil, air, and water are the vital life-supporting systems of this planet Earth. However, the deliberate and accidental introduction of invasive alien plants (IAPs) in the Anthropocene majorly due to the global international trade perturbed the homeostasis of our biosphere. IAPs are considered as one of the major drivers of biodiversity loss and ecosystem degradation. The pervasive threats of IAPs to environmental sustainability and biosecurity are further exacerbated under the COVID-19 pandemic. The environmental disturbances resulting from IAPs can be attributed to several mechanisms/ hypothesis (e.g., novel weapon (NW), enemy release (ER), and evolution of increased competitive ability (EICA), efficient reproductive attributes, and phenotypic plasticity, etc.) deployed by IAPs. Nevertheless, the interrelationship of IAPs with environmental degradation and restoration remain elusive especially in terms of ecological sustainability. Moreover, there is a dearth of studies which empirically assess the synergies of IAPs spread with other anthropogenic disturbances such as climate and land-use change. In this context, the present review is aimed to depict the impacts of IAPs on environment and also to assess their role as drivers of ecosystem degradation. The restoration prospects targeted to revitalize the associated abiotic (soil and water) and biotic environment (biodiversity) are also discussed in detail. Furthermore, the effects of IAPs on socio-economy, livelihood, and plant-soil microbe interactions are emphasized. On the other hand, the ecosystem services of IAPs such as associated bioresource co-benefits (e.g., bioenergy, phytoremediation, biopolymers, and ethnomedicines) can also be vital in sustainable management prospects. Nevertheless, IAPs-ecological restoration interrelationship needs long-term pragmatic evaluation in terms of ecological economics and ecosystem resilience. The incorporation of 'hybrid technologies', integrating modern scientific information (e.g., 'biorefinery': conversion of IAPs feedstock to produce bioenergy/biopolymers) with traditional ecological knowledge (TEK) can safeguard the environmental sustainability in the Anthropocene. Importantly, the management of IAPs in concert with circular economy principles can remarkably help achieving the target of UN Sustainable Development Goals and UN-Decade on Ecosystem Restoration.
\end{abstract}

Keywords Biotic invaders $\cdot$ Climate change $\cdot$ Ecosystem restoration $\cdot$ Ecological resilience $\cdot$ Forest biodiversity $\cdot$ Invasive alien plants $\cdot$ Plant-soil-microbe interactions $\cdot$ Sustainability $\cdot$ Traditional ecological knowledge

\section{Introduction}

The Anthropocene (i.e., human-dominated geological epoch) witnessed a rapid pace of industrialization and urbanization, transmogrifying the global land-use pattern (Lewis and

Prabhat Kumar Rai

prabhatrai24@gmail.com

1 Department of Environmental Science, School of Earth Sciences and Natural Resource Management, Mizoram University, Aizawl, Mizoram, India
Muslin 2015; Bauer and Reynolds 2016; Gornish and dos Santos 2016; Reynolds 2021). Environmental resources are finite in nature and form the very basis of life on this planet Earth. Therefore, the natural resources and biodiversity need to be protected from the multiple anthropocene risks (Edrsi et al. 2020; Díaz et al. 2020; Abhilash et al. 2021). Further, biotic/abiotic components of the environment provide a multitude of ecosystem services such as food, fiber, fuel, timber, carbon sequestration, nutrient cycling, and human well-being (Fig. 1). Unfortunately, environmental pollution caused by anthropogenic activities escalated the concentrations of hazardous heavy metals, organic chemicals, 


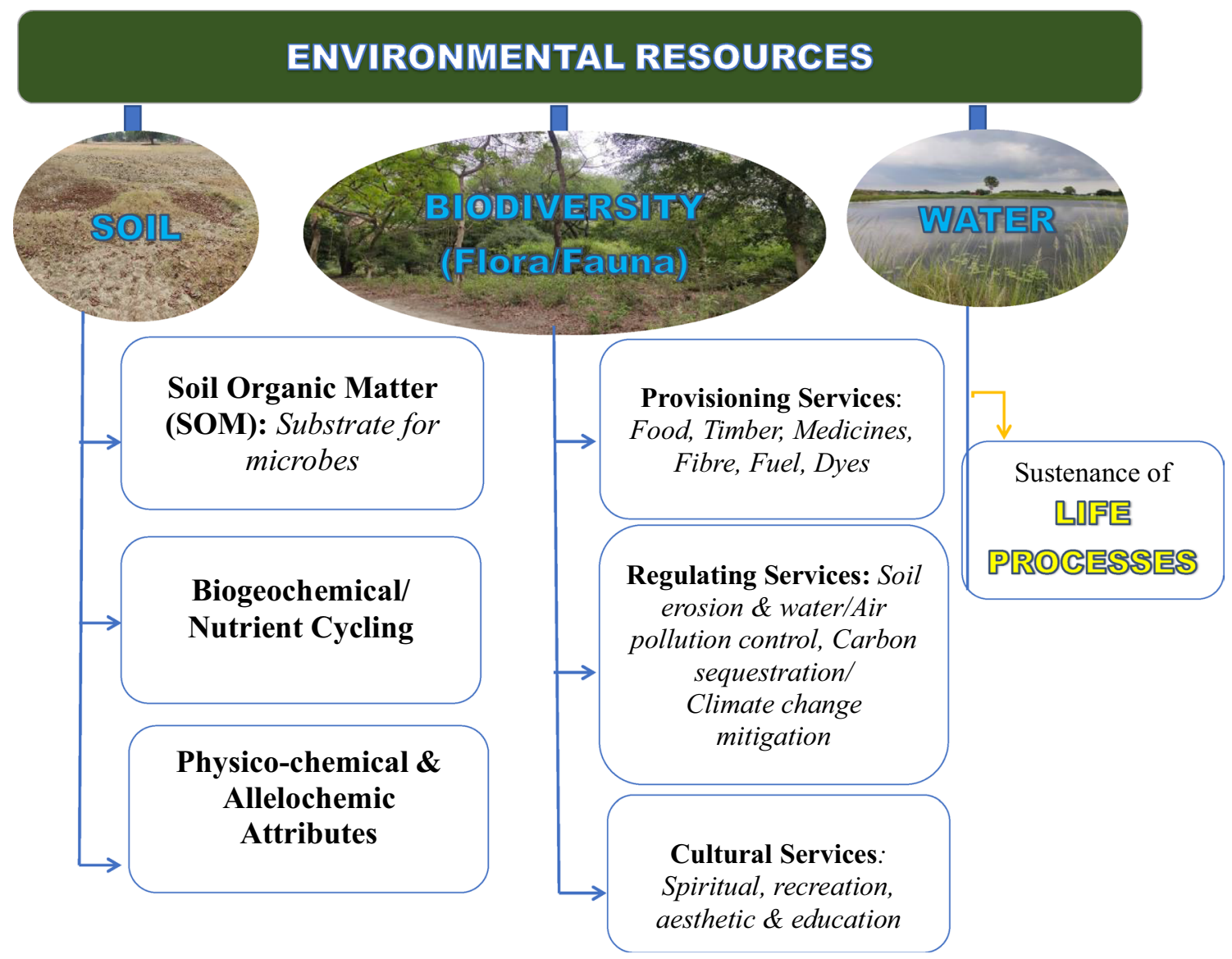

Fig. 1 The multitude of ecosystem services associated with abiotic/biotic complexities of environment, essential for the sustenance of human life, well-being, and livelihood in the Anthropocene

and emerging contaminants such as micro/-nanoplastics in multiple environmental matrices diminished the ecosystem services (Lewis and Muslin 2015; Rai et al. 2021). In this context, though the native biodiversity is considered to be safety-net against the environmental pollution and ecological invasions to safeguard the human health (Kennedy et al. 2002; Swaminathan 2003; Bawa et al. 2021; Crisp 2021), however, its continuous depletion also aroused concern about the loss of its associated ecosystem services, sociocultural attributes, and socio-economic or livelihood aspects. Further, land-use and climate change in conjunction with nitrogen deposition and biotic exchange acted as major drivers of future changes in biodiversity, thereby impacting the global ecosystem services (Sala et al. 2000; IPCC 2013; Pyšek et al. 2020). The recent coronavirus (SARS-Cov-2) upsurge remarkably influenced the IAPs, biodiversity, indigenous agricultural food systems, livelihood of low-income population, and environmental footprint (McElwee 2020; Zavaleta-Cortijo et al. 2020). Incidentally, the anthropogenic pressure on biodiversity is likely to be escalated during post COVID-19 pandemic scenario which warrants sustainable solutions (Bouman et al. 2021).
In addition to environmental pollution, the alteration of ecological complexity and soil resources through invasive alien plants (IAPs) is a pervasive threat to native biodiversity while accelerating the overall process of environmental degradation (Stanek et al. 2020; Allen et al. 2021; $\mathrm{Qu}$ et al. 2021). International trade through several global routes was considered to be the prime drivers in the spread of biotic invaders (Hulme 2021). Biological invasions since its inception in ecological studies were considered as a sort of 'ecological explosions' (Elton 1958). In the present scenario, global estimates of 21 countries suggested that the number of biotic invaders per country have risen by about 70\% since 1970 (IPBES 2019a, b). Further, the International Union for Conservation of Nature (IUCN)-Red List database assessed that IAPs contributed to $25 \%$ of global plant extinctions (IUCN 2017). Globally, the rapid spread of IAPs in the heterogeneous environment can be ascribed to several adaptive mechanisms or hypothesis [e.g. Novel Weapon (NW), Enemy Release (ER), and evolution of increased competitive ability (EICA)], efficient reproductive attributes (e.g., perfection of pollination and vigorous seed output), rapid biomass allocation, herbivore-IAP interactions, and 
phenotypic plasticity (Blumenthal 2006; Blumenthal et al. 2016; Pinzone et al. 2018; Pyšek et al. 2020; Wang et al. 2020; Rathee et al. 2021; Allen et al. 2021). Nonetheless, these mechanisms may be species/habitat specific in triggering the IAPs spread and environmental degradation.

The rapid pace of IAPs infestation in the Anthropocene perturbed the biotic and abiotic components of the environment (El-Barougy et al. 2021; Rathee et al. 2021). To this end, the IAPs have driven the environmental degradation by changing nutrient and pollutant cycling, habitat structure, microbial diversity; hydro-morphology, soil chemistry, water and disturbance regimes (Pyšek et al. 2020; Qu et al. 2021). In contrast, Gao et al. (2020) studied the effects of soil attributes on IAPs and revealed that soil nutrient heterogeneity has driven the growth of plant invaders. Hence, IAPs act as passengers as well drivers of environmental degradation in Anthropocene (Bolpagni 2021). In addition, it has been demonstrated that IAPs possess high phenotypic plasticity and better soil resource utilization in disturbed environment which gives them a competitive advantage over natives, especially under the changing global climate (Funk 2008; Ravi et al. 2009; Hulme 2012; Parepa et al. 2013; Gong et al. 2020). Further, the disturbed landscapes such as landfills/ dumps can also act as IAPs epicentres or hotspots which can adversely affect the other environmental matrices and human health through the release of pollen and toxins (Plaza et al. 2018; El-Barougy et al. 2021).

The present status of environmental perturbation can be realised by the fact that about $33 \%$ of the global land is degraded in nature due to multiple disturbances (Parepa et al. 2013; Nkonya et al. 2016). Further, according to United Nations Development Program (UNDP), 52\% of global agricultural lands are degraded to varying extent, impacting the livelihood of 2.6 billion agrarian people and farmers (Abhilash 2021). Nevertheless, IAPs successfully colonized the marginal lands and depauperate ecosystems, not suited for growing other agricultural crops (Rai and Kim 2020). Past studies have also noted that the integral components of environment such as vegetation dynamics, forest community composition, litter decomposition, and soil nutrient status in protected landscapes are significantly influenced by the spread of IAPs (Aragón et al. 2014; Uddin and Robinson 2018; El-Barougy et al. 2021). It has been well known that almost $99 \%$ of the selected IAPs are used globally as food crops (e.g., wheat, maize, cassava, rice, potato, barley, soyabean, sugarcane, and oats) (Pejchar and Mooney 2009). Interestingly, $70 \%$ of global dietary need is secured by raising these alien food crops (Prescott-Allen and Prescott-Allen 1990; Pejchar and Mooney 2009; Kariyawasam et al. 2021). However, unsustainable practices such as monoculture plantations in agro-forestry/agro-ecosystems facilitated the IAPs spread and concomitantly increased susceptibility towards pathogenic microbes (Chazdon 2008). Several IAPs such as Eichhornia crassipes and Salvinia molesta can adversely influence the productivity of paddy fields (Kariyawasam et al. 2021). Allelochemic compounds released from IAPs (e.g., Rhus typhina) adversely influenced the growth of cultivated plant such as Tagetes erecta (Qu et al. 2021). Furthermore, IAPs in concert with climate change have remarkably affected the global agricultural systems (Ziska et al. 2011; Paini et al. 2016) and hence impose adverse implications on food security. The adverse effects of IAPs on agriculture systems under the event of climate change (e.g., abrupt increase/decrease in temperature and rainfall variables influencing the phenology and soil attributes) are being studied through climatic suitability heat maps, ecological niche and species distribution models (SDMs) (Gong et al. 2020; ElBarougy et al. 2021; Kariyawasam et al. 2021).

Restoration of degraded environment can rejuvenate the forestry/agro-forestry and agroecosystem biodiversity with the revitalization of ecosystem services which can assist in attaining the UN-Sustainable Development Goals (SDGs) (Leclere et al. 2020; Edrsi et al. 2020) (Fig. 2). Further, Fig. 2 lists the environmental challenges in Anthropocene, especially in relation to IAPs and elucidates their interrelationship with several targets of SDGs. In this sense, restoration of degraded environment encompasses a broad range of pursuits such as (a) reclamation of degraded abiotic environment due to mining and hazardous environmental contaminants, (b) revitalization of ecosystem services, and (c) rehabilitation of rare, endangered, and indigenous biodiversity through management of IAPs. Furthermore, explicit studies on plant-soil and plant-soil microbe interactions can be a vital foundation for formulating sustainable ecosystem restoration strategies (Eviner and Hawkes 2008). In Anthropocene, the sustainable restoration of biodiversity (SDG 15) can safeguard the human health under the event of future pandemics (SDG 3) (Bawa et al. 2021). Further, the biodiversity restoration is considered to be the sustainable way of mitigating the effects of climate change (SDG 13). In addition, several Institutions such as convention on biological diversity (CBD), United Nations Convention to Combat Desertification (UNCCD), and Kyoto Protocol widely identified the rapid pace of IAPs lead environmental degradation in Anthropocene as a major challenge for restoration ecologists (Waruru 2018).

The complex interactions among global environmental disturbances in Anthropocene have complicated the task of restoration ecologists (Hobbs and Cramer 2008; Walther et al. 2009; Rai 2015; Early et al. 2016). Concomitantly, these perturbations resulted in paradigm shift in ecological resilience, rehabilitation, self-regeneration, and restoration mechanisms of degraded environment. Several studies have been performed to analyse the impact of IAPs on biodiversity (in terms of 'autecology'/ vegetation ecology) whereas, the study on soil attributes are of paramount 


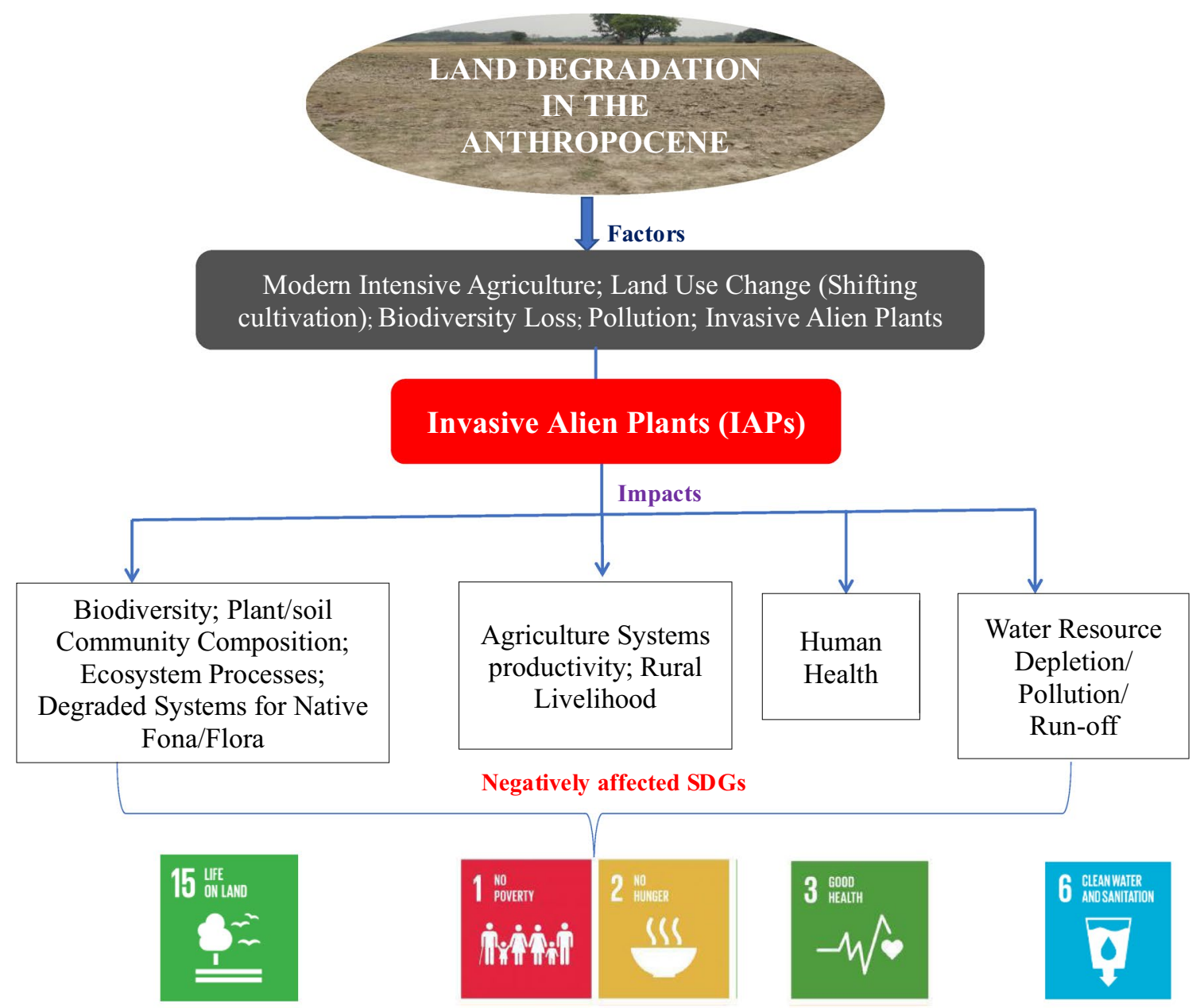

Fig. 2 Drivers of environmental degradation in the Anthropocene with special reference to plant invaders which are interrelated with multiple SDGs; The IAPs can influence the attainment of various

importance in understanding plant invasion ecology. In this respect, several search engines such as SCOPUS, Web of Science, Science Direct, and Google Scholar were visited in quest of the existing voids in subject knowledge. In studying the subject both academic and grey literature were covered. To this end, several keywords such as "Plant invasion and ecosystem degradation", "Invasive alien plants and soil properties", "Invasive alien plants and soil microbes", "Invasive alien plants and restoration" and Plant invasion climate change and land-use" were searched in literature selection methodology to provide a systematic review of the subject. In previous studies, the multifaceted impacts of IAPs are widely documented, however; there is a dearth of studies which describes the environmental degradation and sustainable restoration strategies in an interrelated framework. Henceforth, this review addresses the impacts of IAPs on multiple environmental matrices to assess their holistic effect. To this end, the effects of
SDG targets (1, 3, 6, and 15) and hence inextricably linked with the environmental sustainability

IAPs on biodiversity, soil, and water are discussed in this review. These environmental impacts of IAPs were observed to reverberate up to the level of ecosystem degradation. Importantly, in this review, IAPs driven environmental degradation and restoration are discussed critically in terms of positive and negative implications. In addition, the restoration strategies, capitalizing the role of traditional ecological knowledge (TEK) are described to attain environmental sustainability. The present discussion advocated the use of 'hybrid technologies' (i.e., integrating scientific knowledge, TEK, and scientific co-benefits in terms of environmental remediation and 'bio refinery') for IAPs management and sustainable ecosystem restoration. The implementation of hybrid technologies in ecosystem restoration can be of wider community acceptance and can concomitantly augment in help achieving the target of SDGs and rural livelihood. 


\section{Impacts of Invasive Alien Plants on Environmental Resources}

\subsection{Biodiversity}

The landscape spread of IAPs is widely accepted as pervasive threat to native biodiversity (Pyšek et al. 2020; El-Barougy et al. 2021). On contrary, the rich native biodiversity is considered to be a line of the defence against IAPs infestation in accordance with 'diversity resistance hypothesis' (Kennedy et al. 2002). However, the increased colonization of IAPs in novel ecosystems can adversely influence the native biodiversity and carbon storage (Jackson et al. 2002; Leclere et al. 2020). Globally, it has been estimated that about $17 \%$ of the biodiversity is highly vulnerable to biotic invasions (Early et al. 2016). Further, the geographical landscapes of $15 \%$ of the low Human Development Index (HDI) countries and 16\% of global biodiversity hotspots are highly threatened due to biotic invasions (Early et al. 2016). Adaptability to grow in an environment with spatio-temporal heterogeneity, strong clonal ability, and efficient utilization of resources (e.g., nutrients) can facilitate the IAPs success over the native biodiversity (Wang et al. 2021). In this aspect, study on Parthenium hysterophorus in Himalayan mountain ecosystems revealed the role of phenotypic plasticity, reproductive fitness (e.g., large number of heavier but small-sized seeds), and biomass allocation in the spread of this IAP (Rathee et al. 2021). Further, the adverse effects of IAPs on indigenous or native biodiversity are further exacerbated under the event of high global deforestation rate i.e., 13 million ha ${ }^{-1}$ (Chazdon 2008) and climate change (Pyšek et al. 2020). Climate change in concert with other environmental perturbations influenced the diversity of soil microbes (Young and Larson 2011). In addition, it has been estimated that about 500 million hectares of tropical forests have been lost due to intensive land-use changes which can potentially facilitate the colonization of IAPs (Lamb et al. 2005; Pyšek et al. 2020). In addition to extensive deforestation, IAPs spread is encouraged through practicing unsustainable traditional/modern intensive agricultural practices (Chazdon 2008). Accordingly, multiple anthropogenic disturbances encouraged IAPs spread in forested landscapes. These synergistic interactions of IAPs resulted in an adverse influence on stochastic process of forest succession which eventually turned them into degraded secondary forests (Chazdon 2008; Rai 2009). Anthropogenic activities such as mining can drastically remove the vegetation cover and top-soil and has been estimated to impact an area of 2 million hectares/year worldwide (FAO 2006). In this sense, biodiversity loss through forest degradation alone is predicted to influence the well-being of about 1.6 billion people among which about $74 \%$ are rural people with low livelihood opportunities (Abhilash 2021).

The 'invasion windows' generated by anthropogenic disturbances allow IAPs to act as passenger along with the potential plant traits such as; prolific seed production, efficient seed dispersal, greater propagules mobility, and allelochemic attributes (Sakachep and Rai 2021). Interestingly, these traits associated with IAPs can help them to establish in novel habitats and threaten the native biodiversity (Rai and Singh 2021). Accordingly, IAPs act as carriers along with the anthropogenic disturbances such as habitat destruction through deforestation. In view of this arrested forest development and infested IAPs, Food and Agriculture Organization (FAO) estimated that secondary degraded forests constitute about $60 \%$ of global forest area (FAO 2005). In addition, United Nation's (UN) Intergovernmental Platform for Biodiversity and Ecosystem Services (IPBES) predicted that about one fifth of the Earth's land surface is at risk due to biotic invaders therefore, considered them as major driver of biodiversity loss (IPBES 2019a, b). Accordingly, Earth Summit in Rio de Janeiro, 1992, therefore, delineated the IAPs spread in the forestry/agroforestry systems as one of the main causes in impacting the environment, biodiversity, human health, and ecosystem services. Henceforth, the threat of IAPs to global biodiversity hotspots and associated environmental degradation is of concern to conservation and restoration ecologists. The IUCN Invasive Species Specialist Group (ISSG) developed two global databases i.e., the Global Invasive Species Database, which provides explicit details of specific biotic invaders and the Global Register of Introduced and Aliens (Pyšek et al. 2020). Further, Delivering Alien Species Inventories for Europe (DAISIE) and North European and Baltic Network on Invasive Alien Species (NOBANIS) projects aimed to monitor the biodiversity and health effects of IAPs. In addition, other global efforts to minimize the effects of IAPs and strengthen biodiversity conservation were channelized through institutional and regulatory organizations such as Global Biodiversity Information Facility (GBIF), World Database on Protected Areas (WDPA), Global Register of Introduced and Invasive Species (GRIIS), Invasive Species Compendium (CABI), and Environmental Impact Classification for Alien Taxa (EICAT) (McGeoch and Jetz 2019; Leclere et al. 2020).

\subsection{Soil}

The adverse impacts of IAPs on soil and associated ecosystem processes can remarkably facilitate the environmental degradation. The different steps involved in ecological succession and spread of IAPs are inextricably associated with plant-soil/plant-soil-microbe interactions 


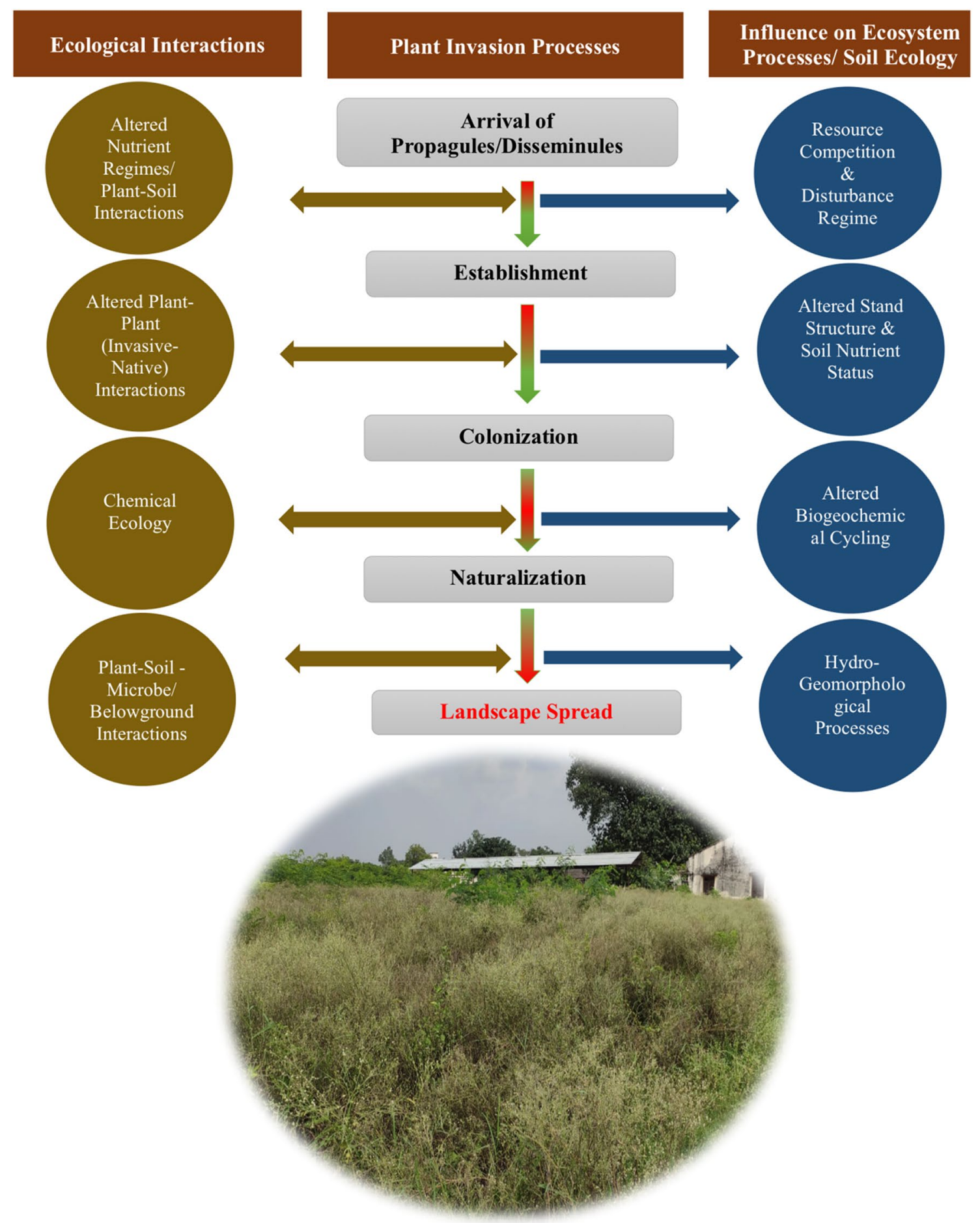

Fig. 3 The interrelationship of plant invasion ecology /their ecological succession mechanisms/hypotheses with plant-soil-microbe interactions, influencing the soil physic-chemical/biological characteristics and ecosystem processes

(Fig. 3). The changes in soil physic-chemical attributes, biogeochemical cycling, and hydrogeomorphological processes are tightly linked with different steps (propagules arrival, establishment, colonization, and landscape spread) in IAP succession (Fig. 3). The successful colonization of IAPs such as Rhus typhina can adversely impact the soil physico-chemical and microbial attributes (Qu et al. 2021). 


\subsection{Impact of IAPs on Soil Physicochemical Properties}

The effects of IAPs on soil physico-chemical characteristics can be variable in different ecosystems. In this respect, the effects of Chromolaena odorata on soil attributes were noted higher in savannah when compared with forest ecosystems (Koné et al. 2021). In the context of soil physico-chemical characteristics, certain IAPs (e.g., Bromus tectorum, Eucalyptus tereticornis, and Phragmites australis) positively altered the physical properties of soil or associated microtopography (Bargali et al. 1993; Windham and Lathrop 1999; Kumar et al. 2021). Such influences of IAPs on soil attributes were attributed to increased soil porosity due to the presence of shallow fine roots. Further, in the case of multiple IAPs-natives interactions, multidirectional effects can result in a considerable divergence in soil physicochemical attributes (Stefanowicz et al. 2018). In this aspect, colonization of IAPs (e.g., Lantana camara and Ageratina adenophora) in chir pine forests of Central Himalayan region increased soil physico-chemical parameters such as soil moisture, porosity, nitrogen $(\mathrm{N})$, potassium $(\mathrm{K})$, and organic $\mathrm{C}$ while there was noted a decrease in bulk density (Kumar et al. 2021). Herein, the increased nutrient status in enriched soil substratum of chir pine forests was predicted to facilitate the spread of L. camara and A.adenophora. Conversely, certain IAPs such as E. tereticornis reduced the organic matter, water holding capacity, and nutrient levels, thereby degrade the soil physico-chemical parameters (Bargali 1993; Parepa et al. 2013; Qu et al. 2021). In another study, the infestation of Prosopis juliflora was observed to increase the soil $\mathrm{pH}$ but decreased exchangeable sodium, calcium, and magnesium when compared with un-invaded lands (Shiferaw 2021). In addition, the long term colonization $H$. mantegazzianum impacted the physical, chemical, and biological attributes of soil (Jandova et al. 2014). Therefore, depending on specific IAPs, their impacts on soil physico-chemical characteristics can be positive and negative. Several studies investigated the strong interrelationship between IAPs success and soil attributes. In this sense, the infestation of IAPs [e.g., Solidago gigantea, Fallopia japonica, Impatiens glandulifera (Himalayan Balsam), and Heracleum mantegazzianum] increased the nutrient stock and aboveground biomass when compared with un-invaded vegetation (Dassonville et al. 2008). Thus, the comparative ecological investigation of invaded and un-invaded sites displayed divergent soil chemistry and plant community composition (Dassonville et al. 2008).

In general, the colonization of IAPs in specific landscape can contribute towards homogenisation of soil conditions (Qu et al. 2021). The multiple soil attributes (such as litter dynamics, soil carbon $(\mathrm{C}), \mathrm{N}$ mineralisation, phosphorus $(\mathrm{P})$ content, allelochemic concentrations, enzymatic activity, and microbial diversity) can be significantly influenced by the colonization of IAPs (Ni et al. 2020) (Table 1). These IAPs induced changes in soil pools impose persistent effect on soil structure or processes which can extend to landscape level, thereby altering the geomorphology (Fig. 4). In this context, Fig. 4 represents the interrelationship between IAPs and native traits. The interrelationship of plant traits such as litter chemistry, mineralization, soil organic matter, cation exchange, root exudates, and phenology with soil physical-chemical attributes (e.g., soil-temperature, $\mathrm{pH}$, water holding capacity, and microbial biomass) can influence the IAP dynamics. The alterations in soil nutrient pool can potentially impact the plant community dynamics. In this sense, increased soil $\mathrm{N}$ facilitated the colonization of an IAP Flaveria bidentis, which caused elimination of another plant invader i.e., Bidens sp. (Huangfu and Li 2019). Another study revealed that an enhanced level of nutrients such as soil $\mathrm{N}$ was demonstrated to facilitate the landscape spread of B. tectorum, (annual cheat grass) by out-competing the native plants (Morris et al. 2016).

\subsubsection{Impact of IAPs on Soil Biochemical Properties}

Plant invaders remarkably influence the biochemical properties of soil (Qu et al. 2021; Shiferaw 2021). In general, IAPs enhance soil enzymatic activities greater than natives and differential enzyme levels can act as proxy for N-mineralization (Ehrenfeld 2003; Shiferaw 2021). Interestingly, allelochemicals in soil released from IAPs can exert immediate harmful effects and also potentially persist as allelopathic legacy to influence the native biodiversity, in longterm (Fabbro and Prati 2015). Interestingly, IAPs spread is also impacted by release of allelochemicals (e.g., phenolic/ sesqui-terpenoid compounds) and their influence on soil chemistry (Qu et al. 2021). The allelochemic compounds or secondary metabolites emitted from IAPs can also influence the litter decomposition, root exudates chemistry, and subsequent release of nutrients (Ehrenfeld 2003; Qu et al. 2021). Individual plant-based simulation model (e.g., ECOTONE) revealed that soil texture, in concert with allelopathy influenced the landscape spread of $\mathrm{a}_{3}$ IAP Acroptilon repens which on long-term infestation increased the extent of soil erosion (Goslee et al. 2001; Qu et al. 2021).

Plant invaders such as Casurina equisetifolia are considered to produce more litter with slow decomposition than natives (e.g., Melaleuca quinqenervia) (Greenway 1994). Further, IAPs influence litter persistence their quantity and quality thereby, impacting the litter dynamics of infested landscape (Qu et al. 2021). The IAPs litter (e.g., those of Lantana camara, Myrica faya, and $P$. australis) also differ in tissue chemistry owing to high $\mathrm{N}$ content, allelochemic potential, and decomposition rate, when compared with natives (Raizada et al. 2008). Therefore, variability in litter 


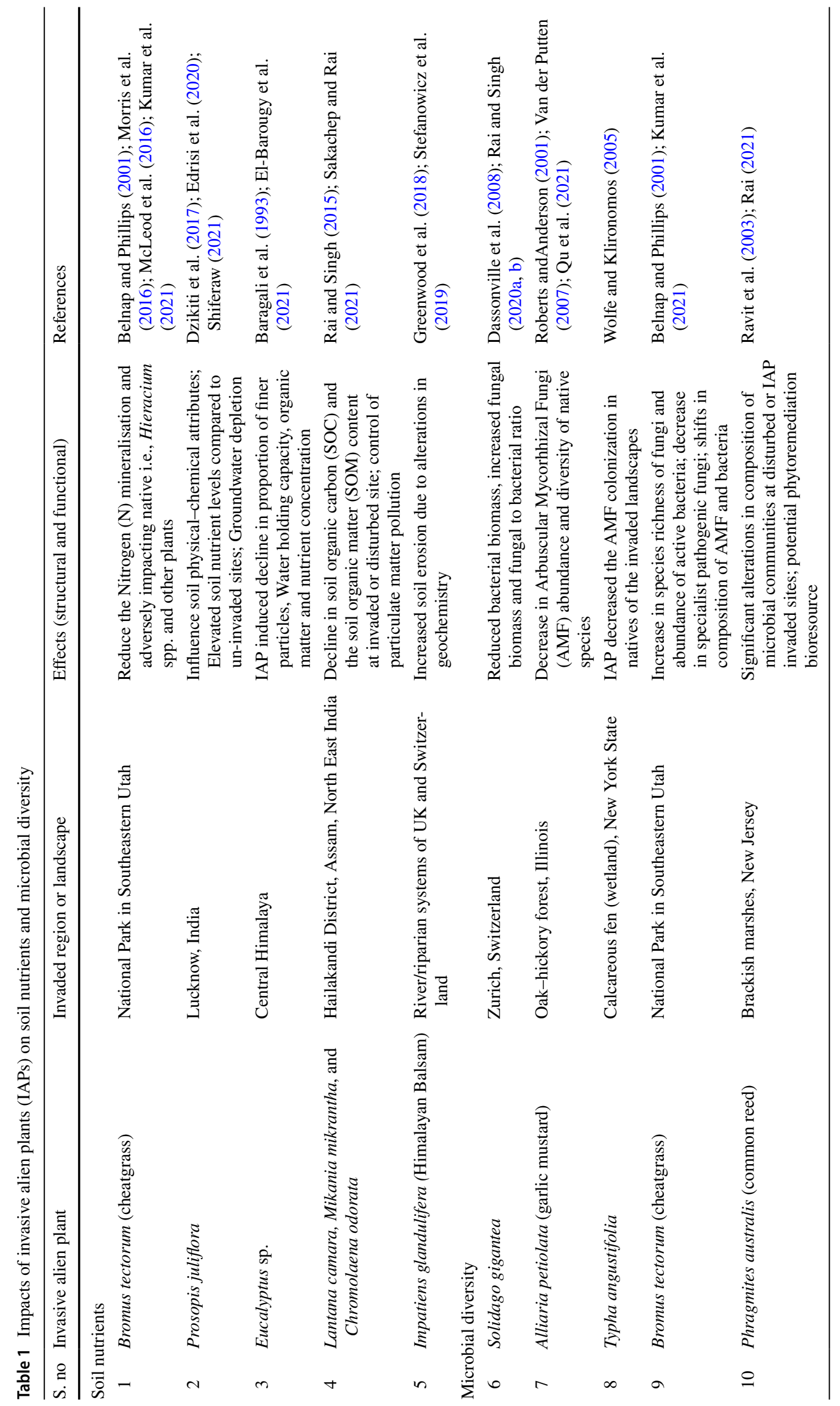




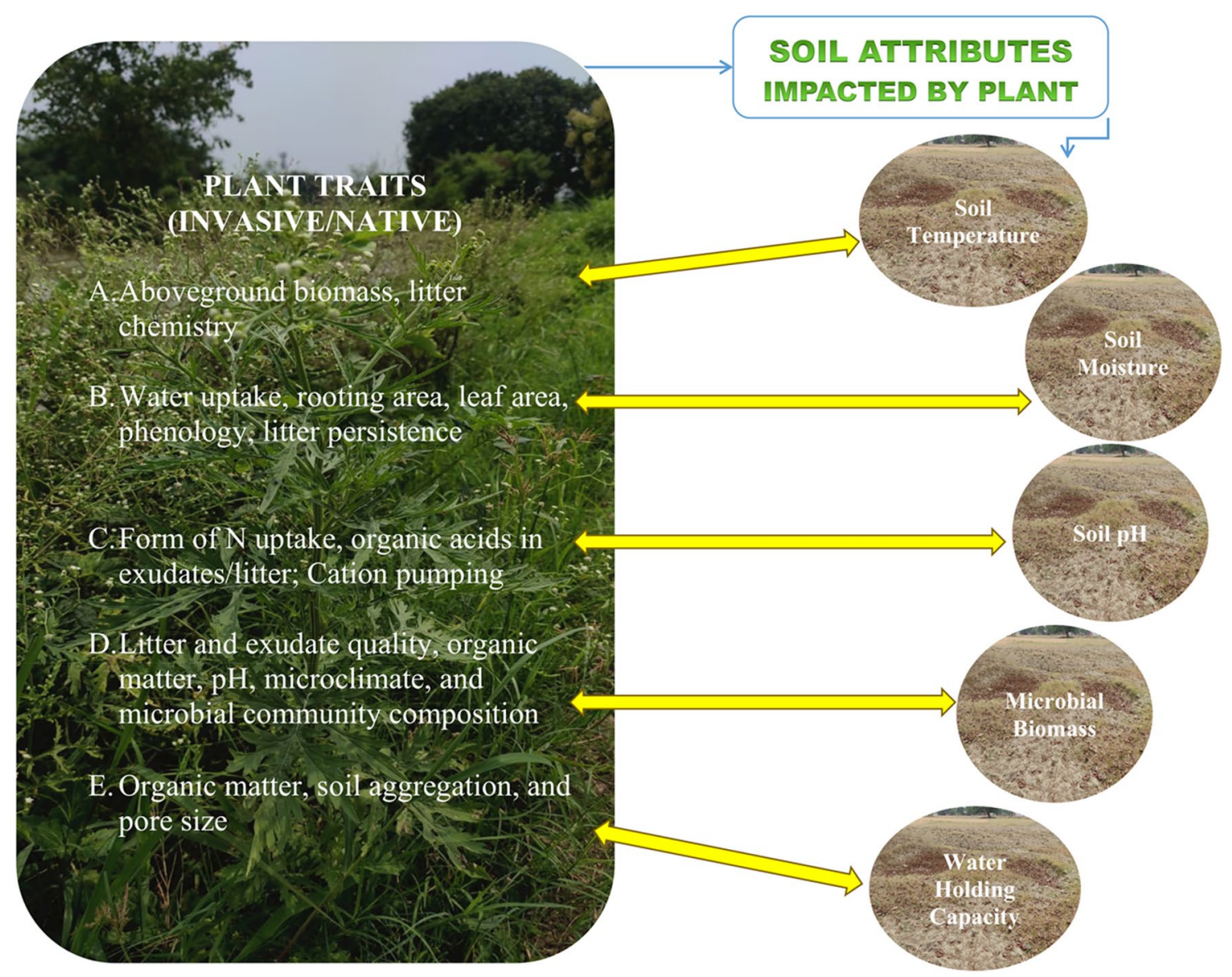

Fig. 4 Mutual intricate interrelationship between plant traits and soil health (physico-chemical and biological parameters) with significant ecosystem restoration implications

persistence can exert a profound impact on soil nutrient status, stand structure, biogeochemical cycles, and hydrogeomorphological processes (Jandova et al. 2014; Wang et al. 2021).

Certain IAPs such as L. camara and P. australis demonstrate higher N-use efficiency than natives; thereby influence the mineralization and $\mathrm{N}$-dynamics of invaded landscapes (Wang et al. 2021). In addition, IAPs such as Lepidium latifolium influence the carbon dynamics of invaded regions due to their higher biomass, net $\mathrm{CO}_{2}$ assimilation rate, clonal spread, and lower leaf construction costs (Ehrenfeld 2003). Moreover, the long-term infestation of IAPs such as C. equisetifolia can competitively eliminate the soil stabilizing grasses, causing steepening of slopes, and resulting in shoreline erosion, which eventually influence the geomorphology of the infested landscape (Raizada et al. 2008). An IAP Melaleuca quinquenervia owing to its phenological attributes and timing of litter deposition can impact the soil, micro-topography, and geomorphology in shallow wetlands (Boon 1997; Wang et al. 2021). Table 1 lists the impacts of IAPs on soil nutrients and microbial diversity.

\subsubsection{Impact of IAPs on Soil Microorganisms and Plant- Microbe Interactions}

The effects of IAPs on plant-soil microbe interactions can remarkably influence the soil biogeochemistry and competitive dynamics of native plant community (Qu et al. 2021). In this respect, IAP s such as Impatiens glandulifera can remarkably influence the soil microbial diversity, thereby enabling the niche construction to encourage the spread of IAPs (Stefanowicz et al. 2019). The adverse effects of IAPs can also contribute to environmental degradation (Wolfe and Klironomos 2005; Eviner and Hawkes 2008; Qu et al. 2021). In this sense, Kumar et al. (2021) observed a significant increase in microbial biomass $\mathrm{C}$ and $\mathrm{N}$ in chir pine forest invaded with $L$. camara and A.adenophora, with explicit seasonal variation trends (i.e., rainy $>$ summer $>$ winter). Conversely, soil microbial biomass $\mathrm{C}$ declined in forest ecosystems which were invaded with $C$. odorata (Koné et al. 2021). In addition, the species-specific allelochemic extracts released from IAPs can influence the plant-soil-microbe interactions (Qu et al. 2021). 
Microbial communities are considered to act as soil health indicators which can be vital parameter in the restoration of degraded environment (Li et al. 2015). Accordingly, plant-soil-microbe interactions are considered to be at the heart of revitalizing the degraded environment $(\mathrm{Qu}$ et al. 2021). Microbial diversity can influence the plantsoil interactions by increasing the vegetation establishment, soil organic matter, efficient mobilization of nutrients, and soil aggregation (Eviner and Hawkes 2008). The use of molecular tools such as 16S rDNA sequencing revealed that invasion of Bidens alba (formerely B. pilosa) remarkably altered the soil bacterial community composition when compared with uninvaded site (Wang et al. 2020). In this respect, the diversity of native arbuscular mycorrhizal fungi (AMF) was noted as a better tool in environmental restoration than allocthonous species (Caravaca et al. 2003). However, the IAPs can shift about $80 \%$ of the AMF diversity from with natives towards their side and get tightly associated (Callaway et al. 2004). The AMF association with IAPs potentially facilitate their colonization and landscape spread (Hawkes et al. 2006).

Plant soil feedback (above and belowground interactions) and herbivory in disturbed ecosystems play a vital role in the success of IAPs (Fukano et al. 2013; Allen et al. 2021). The association of microbes, especially those of mycorrhizal fungal diversity is extremely vital in sustenance of plant diversity and ecosystem resilience (Van der Heijden 1998; Koné et al. 2021). These secondary metabolites impact the belowground microbial diversity as demonstrated in the case of Alliaria petiolata, which pertub the AMF association with natives (Van der Putten 2007; Qu et al. 2021). Such adverse impact of IAPs in disrupting microbial association became the basis for the 'Mycorrhizal Degradation Hypothesis' (Vogelsang et al. 2004). Henceforth, the below ground community significantly influence the aboveground plant composition and hence colonization of IAPs.

Molecular tools (16S rRNA gene sequencing) also revealed that the invasive spread of IAPs such as $A$. adenophora (formerly Eupatorium adenophorum) was ascribed to their close association with the microbial diversity and the increased levels of nitrate in soils of invaded landscape (Kong et al. 2017). Conversely, the plant invaders can also enrich the soil microbial diversity in in novel landscapes (Qu et al. 2021). In this aspect, I. glandulifera increased the diversity of soil fungal and bacterial populations in newly colonized land surfaces (Gaggini et al. 2018). Similarly, several IAPs (e.g., Centaurea stoebe and B. tectorum) facilitate the colonization of nutrient (e.g., N) cycling bacteria, thereby linked to ecosystem functioning (McLeod et al. 2016). Therefore, unravelling the plant-soil-microbe interactions is necessary in elucidating the IAPs spread and restoration mechanisms.

\subsubsection{Invasive Alien Plants Induce Soil Erosion and Desertification}

Plant invaders can perturb the soil attributes which result in soil erosion to exacerbate the environmental degradation. In this respect, Pejchar and Mooney (2009) reported that IAPs can alter the soil stability through alterations in physico-chemical and biological characteristics, thereby causing soil erosion. Invasions by noxious IAPs, such as spotted knapweed (C. stoebe), leafy spurge (Euphorbia esula) and cheat grass (B. tectorum) may have profound impact on the soil quality of the grassland ecosystems (Gibbons et al. 2017), which may induce environmental degradation. Likewise, another IAP of Mediterranean ecosystem i.e., Acacia dealbata reduced the native plant diversity by adversely affecting the soil chemistry and microbial functioning (Lazzaro et al. 2014). In addition, the infestation of certain IAPs such as I. glandulifera increased the rate of soil erosion, as compared to un-invaded landscapes (Greenwood et al. 2018).

The IAPs can guide the conversion of perennial grasslands into desert scrublands (Jackson et al. 2002; Ravi et al. 2009). This land-use change can impact the global climate, biodiversity, biogeochemical cycles, and food security. IAPs infestation in grasslands can remarkably influence the fire regime, soil nutrient status, and soilerosion rates (Schlesinger et al. 1990; Kumar et al. 2021). These IAPs induced alterations in grassland community perturb the heterogeneity of soil resources and convert them to exotic annual degraded grasslands which can further pave the way for desertification. Furthermore, the spread of biotic invaders can be facilitated under the event of climate change which remarkably accelerates the process of environmental degradation (Rai and Singh 2020a, b). The continuous connected patches of exotic grasslands can enhance the fire cycles; alter the soil attributes, wind erosion rates, and soil erodibility, which facilitate the process of land degradation (Ravi and D'Odorico 2008). Interestingly, after the invasion-fire interactive cycle, certain organic compounds are emitted which induce varying levels of soil water repellency, depending on the soil attributes, duration of fire, intensity of fire, and vegetation type (Doerr et al. 2000; Allen et al. 2021). The characteristic soil water repellency is demonstrated to impact the soil moisture (both adsorption and retention) which remarkably attenuate the inter-particle bonding forces, thereby increasing the susceptibility of soil towards wind/ water erosion (Ravi et al. 2006; Acharya et al. 2018; Bolpagni 2021). Therefore, IAPs induced redistribution of soil resources and plant community composition in long-term can result in soil erosion, desertification, and eventually environmental degradation. 


\subsection{Water}

Plant invaders can exert a profound impact on global water resources. IAPs can perturb the aquatic ecosystem health and diminish the ecosystem services of Ramsar wetlands (Pathak et al. 2021). In freshwater ecosystems, the aggressive IAPs can transmogrify the aquatic ecology (Bolpagni, 2021). Global aquatic invaders are predicted to impose an economic loss of US $\$ 345$ billion (Cuthbert et al. 2021). Interestingly, IAPs of aquatic systems are equipped with certain specific traits (e.g., high biomass, deep roots, and high evapo-transpiration) which can reduce water flow, water holding capacity, and other soil-physico-chemical attributes. These IAP traits induced alterations in soil-water systems which can increase the flood frequency, soil erosion, and land degradation (Pejchar and Mooney 2009). Several IAPs such as $M$. quinquenervia and Eucalyptus species are equipped with extensive deep tap roots systems which enable them to exploit an enormous quantity of the ground water (Schmitz et al. 1997). Further, several IAPs such as B. tectorum, and Tamarix ramosissima, owing to their functional traits (greater leaf area, high water demand, and higher evapotranspiration), tends to exploit the water resources better than natives and thus influence the hydro-dynamics, fluvial processes, and habitat ecology of the invaded site (Graf 1978; Melgoza et al. 1990; Bolpagni, 2021). In this respect, Prosopis spp. was demonstrated to exploit more groundwater than co-occurring neighbouring native tree (Vachellia karroo) (Dzikiti et al. 2017). Accordingly, removal of Prosopis spp. resulted in groundwater recovery. In this aspect, geochemical and modelling studies revealed that alien trees (e.g., Acacia mellifera, Dichrostachys cinerea, Eucalyptus camaldulensis, Prosopis glandulosa, and Tamarix ramosissima) adversely influenced the groundwater recharge of invaded landscapes (Acharya et al. 2018). Thus, biotic invaders tend to use an enormous amount of water, which caused remarkable shift in the water table and socio-ecological regimes (Gaertner et al. 2014). It has been exemplified through a study on Prosopis pallida ( $\mathrm{N}$-fixing IAP in arid regions of Hawaii Island) which intensively exploited groundwater resources eventually perturbing the integrity of soil structure (Dudley et al. 2014).

Food and Agriculture Organization (FAO) Database on Introductions of Aquatic Species (DIAS) comprises the biotic invaders in freshwater and marine environment (FAO 2019). Several countries such as South Africa are widely recognised as 'dark continent' in terms of severe IAPs infestation, especially in Riparian habitats (Holmes et al. 2005; Richardson et al. 2007). Riparian habitats are of particular socio-ecological/socio-economic relevance as they act as 'critical transition zones' between aquatic and terrestrial ecosystems (Ewel et al. 2001; Richardson et al. 2007). In riparian habitats of South Africa, the widely distributed woody IAPs are Melia azedarach and Salix babylonica while Arundo donax is non-woody (Foxcroft et al. 2003), Further, IAPs such as C. odorata and L. camara are identified as potential shrubs in South Africa (Foxcroft et al. 2003). These IAP trees are observed as driving factors for the Riparian habitat degradation (Hood and Naiman 2000). In this context, other factors disrupting Riparian habitat ecology are conversion of forested landscapes to agriculture systems (Kentula 1997), frequent floods with deposition of silt (Holmes et al. 2005), and release of hazardous pollutants in the surrounding catchment (Richardson et al. 2007; Singh and Rai 2016; Rai et al. 2019; Rai and Singh 2020a). In addition to the direct influence of IAPs on water, indirect impacts can also be observed by altering the soil attributes and fire regimes. For example, the extensive infestation of tree IAPs can drastically influenced the soil stability and fire regimes and therefore exerting adverse impacts on river geomorphology (Holmes et al. 2005). Plant invaders can also influence the quantity of surface and ground water, which are in interface with the soil (Shackleton et al. 2019).

The adverse effects of IAPs in water resources can also result in loss of aesthetic and economic values. In this sense, IAP such as Tamarisk invasion in aquatics caused an economic loss around US\$52 million annually (Zavaleta 2000). Another IAP, Castor canadensis imposed adverse impact on water quality and increased the flood risk (Lizarralde 1993). In addition, Acacia mangium exerted a profound impact on environment, socio-economy, and rural livelihood through alteration of the water quality (Souza et al. 2018; Pathak et al. 2021). Therefore, there exists an urgent need to formulate the sustainable restoration strategies to mitigate the water, soil, and biotic resource degradation.

\section{Restoration of IAPs Invaded Ecosystems}

Restoration of the degraded environment is quite challenging in Anthropocene due to complex synergistic interactions among IAPs, climatic variables, land-use change, and other human-mediated disturbances (Gong et al. 2020). Restoration ecologists adopted a plethora of strategies to maintain the biodiversity and resilience of the global ecosystems under the event of IAPs infestation (McGeoch and Jetz 2019; Bawa et al. 2021; Leclere et al. 2020). These complex interdisciplinary interactions need to be studied for formulating sustainable restoration strategies, as was observed in a case study on the highly invasive Fynbos plant species of South Africa (Gaertner et al. 2012). However, several restoration strategies such as physical removal or eradication of IAPs were observed to exert adverse effects on the holistic ecosystem health in several case studies (Zavaleta et al. 2001; Bauer and Reynolds 2016; Gornish and dos Santos 2016; Reynolds 2021). Therefore, for attaining sustainability 
paradigm in environmental restoration, long-term restoration/rehabilitation efforts should go in tandem to conserve the ecosystem benefits and services while managing the IAPs (Montoy et al. 2012; Pathak et al. 2021).

In the management of biological invasions, the explicit assessment of bidirectional feedbacks of soil on plant community dynamics and plant diversity on soil attributes are extremely vital foundation for formulating sustainable ecosystem restoration strategies (Eviner and Hawkes 2008; Koné et al. 2021). In addition, the site conditions [(competitive, stressful and disturbed as per Grime (2001); high fertility and low fertility as per Chapin (2003)] can also influence the plant community dynamics, and hence, the ecosystem restoration process (Eviner and Hawkes 2008; Kumar et al. 2021). The colonization of IAPs can impede the ecosystem restoration processes through specific traits and influencing the soil attributes (Stefanowicz et al. 2019; Gao et al. 2020; Kumar et al. 2021). In this aspect, the colonization of invasive red oak (Quercus rubra) tree produced litter of high C/N ratio with low decomposition (Stanek et al. 2020). Here, in addition to influencing the soil attributes, invasive red oak also negatively influenced species richness and cover of understory vegetation. Therefore, by modifying the soil attributes and understory plant community dynamics, invasive red oak can changed the structure and function of ecosystems. Thus, there is an intricate association among soil health, plant diversity, and eco-restoration process.

Importantly, in relation to plant a trait there exists a tradeoffs among the highly variable soil conditions which need to be elucidated in context of formulating sustainable restoration strategies (El-Barougy et al. 2021; García-díaz et al. 2021). Explicit evaluation of trade-offs will assist in planting suitable trees in multiple soil conditions (Eviner 2004; El-Barougy et al. 2021). Among various plant traits, litter persistence in terms of its chemistry and structure is the most important parameter to influence soil moisture, temperature, $\mathrm{pH}$, available inorganic $\mathrm{N}$, Available inorganic $\mathrm{P}$, microbial biomass $(\mathrm{C}, \mathrm{N}, \mathrm{P})$, and soil aggregation (Eviner and Chapin 2003; Stanek et al. 2020; Kumar et al. 2021; Wang et al. 2021).

The restoration and rehabilitation strategies of IAP invaded sites should be formulated in a manner so that that they revitalize different biophysical complexities of environment, ecosystem functioning, and ecological services (Lamb et al. 2005; Pathak et al. 2021). In addition, forest ecosystem restoration, rehabilitation, and regeneration are urgently required for maintaining the sustainable ecosystem services as well as rural livelihoods which are threatened with IAPs colonization (Chazdon 2008; Stanek et al. 2020). Importantly, the restoration strategies (in terms of revitalizing the biodiversity and ecosystem services) of invaded sites should be implemented after explicitly studying the extent of ecosystem degradation (Fig. 5). As shown in Fig. 5, for attaining a sustainable restoration approach different steps (reclamation, rehabilitation, agroforestry/native tree plantation, and assisted/natural regeneration) can be formulated depending on the extent of site/IAP-specific impact on environmental degradation. Accordingly, at particular sites where land-use changes are less intensive, the pollinating/dispersal agents can also aid in restoration by ensuring seed rains between interconnected forest and agricultural patches (Lamb et al. 2005; García-díaz et al. 2020). In this aspect, Lamb et al. (2005) also emphasized that such restoration strategies are cost-effective way of reclaiming environmental degradation and concomitantly, contributing to sustainable rural livelihood. In contrast, the sites of intermediate land degradation with intact soil surfaces, but devoid of pollinators can opt for reforestation programme (Lamb et al. 2005). In this context, the plantation of potential native or agroforestry species (Fig. 5) can be useful in terms of restoring ecosystem services and rural livelihood (Chazdon 2008; Banerjee et al. 2021).

For sustainable ecosystem restoration, the scientific or experimental researches can be conducted to explicitly optimize the implementation of specific strategies. In some degraded ecosystems, passive restoration strategies were found to be more effective in terms of cost and environmental sustainability (Prach et al. 2007), than intensive mechanical approaches (Sampaio et al. 2007; Banerjee et al. 2021). Therefore, at the sites with self-regenerating degraded lands, the application of intensive strategies such as mechanical plantation, grass removal, and ploughing can impede the natural un-assisted sustainable restoration (Sampaio et al. 2007). Further, the tree plantations though enhance the carbon sequestration potential of disturbed landscapes, however; such emerging forests can also make the site ripe for infestation with potential stress-tolerant IAPs (Laurance et al. 2006).

In addition to biodiversity, restoration of the water system can also assist in mitigating the environmental degradation. In this respect, the identification of ecological indicators can be useful to assess the extent of ecosystem degradation and formulating sustainable restoration strategies in aquatic ecosystems (Rai and Singh 2020a, b). Especially, restoration of IAPs invaded riparian habitats being at soil-water interface is given considerable attention in view of immense ecological/economic values (Pattison et al. 2017). The plant invaders such as I. glandulifera and $F$. japonica were observed as ecological indicators of riparian habitats (Pattison et al. 2017). In this aspect, Smith et al. (2007) also noted that IAPs acted as the ecological indicators of riparian habitat quality. Further, IAPs in conjunction with land-use change can remarkably impacted the functional plant traits, aquatic biodiversity, and biogeochemical cycling in the wetland systems (Roy et al. 2019). In riparian habitats the restoration through re-introduction of native trees plantation should be 


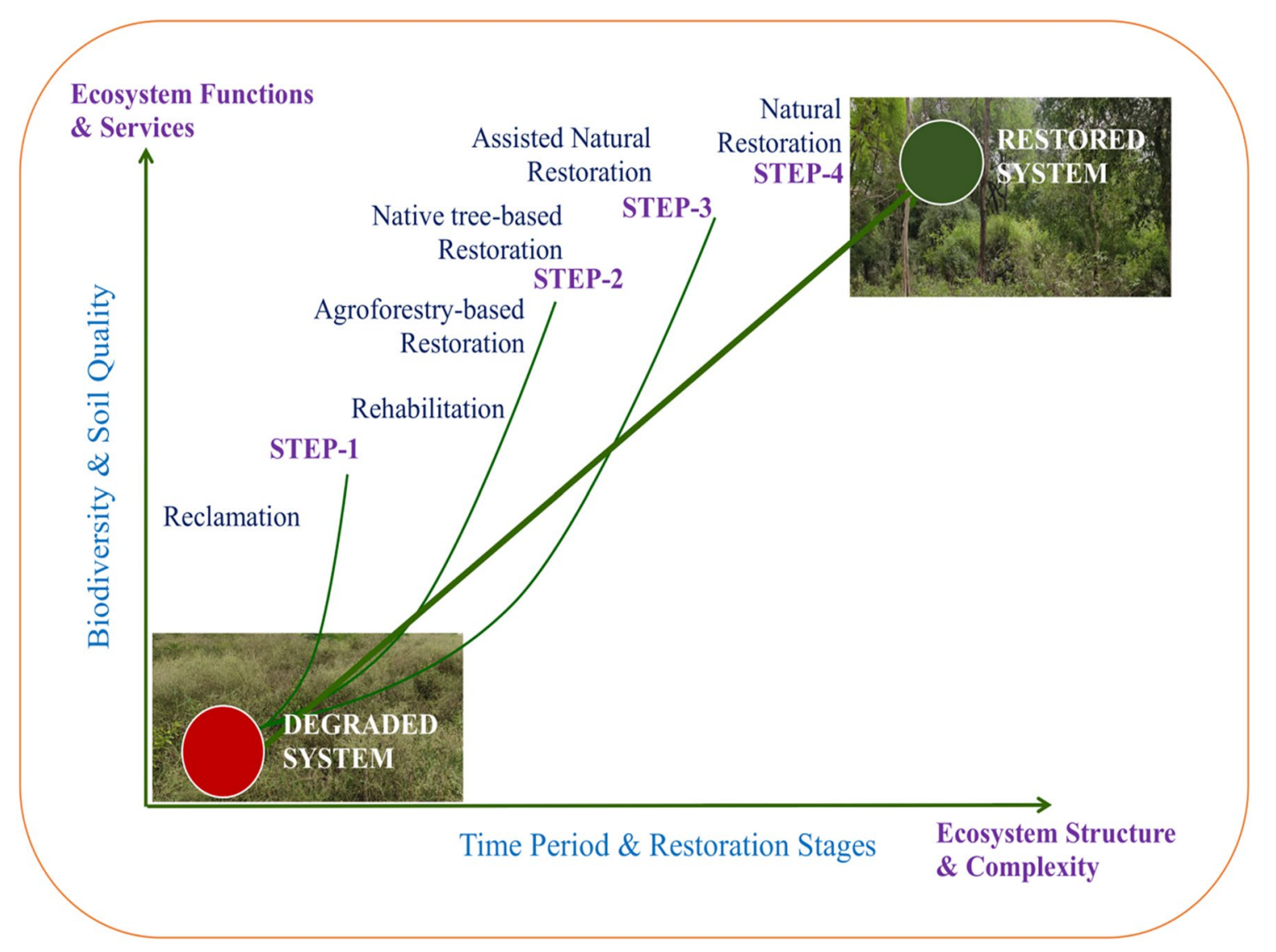

Fig. 5 The underlying ecological processes to transform the degraded ecosystems to restored systems; The judicial options for adequately formulating the ecosystem restoration strategies (e.g., reclamation, rehabilitation, agroforestry/native tree plantations, and assisted/natu-

mediated through hydrological and geomorphological attributes (Holmes et al. 2005; Richardson et al. 2007). However, restoration efforts in riparian habitat invaded with IAPs are faced with several challenges. The abiotic- biotic thresholds, pervasive anthropogenic disturbances (e.g., water extraction), land-use changes (e.g., cultivation of food crops lead eutrophication/sediment deposition), floods induced IAPs transport, and decreased ecosystem resilience are the challenges in the restoration of riparian habitats (Richardson et al. 2007; Pathak et al. 2021). In this aspect, certain IAPs such as Acacia mearnsii, Solanum mauritianum, and C. odorata are having persistent seed banks as invasion legacy, which impose serious challenge to restoration ecologists (Pieterse and Boucher 1997; Holmes et al. 2005; Rai and Kim 2020). The persistent seed banks remaining at the site can rejuvenate, thereby resulting in the failure of the restoration efforts. Henceforth, Holmes et al. (2005) recommended an explicit study on recruitment of native vegetation, dispersal, and seed bank dynamics to augment the sustainable restoration efforts in riparian habitats. The persistent seed bank is vital legacy which can potentially modulate the ral regeneration), based on the state of environmental degradation (low to high- $X$ axes), need of revitalizing the biodiversity/ecosystem services ( $Y$ axes-left), and time/cost-effectiveness (Y axes-right) of implemented strategies (Redrawn and amodified after Chazdon, 2008)

regenerative potential and predict future community dynamics (Gioria and Pyšek 2016). Interestingly, the alterations in seed bank dynamics can act as an indicator of IAPs induced environmental degradation and driver of secondary invasion (Gioria and Pyšek 2016). Therefore, the future studies should explicitly study the seed bank legacy of IAPs to prevent the secondary invasion, thereby facilitate sustainable management.

In a nutshell, restoration of IAPs induced degraded environment can be attained through the recovery of its biotic/ abiotic components (such as soil, water, and biodiversity) and diminished ecosystem services. Forest biodiversity restoration can make the ecosystems resilient which can withstand anthropogenic stressors such as IAPs, environmental pollution, $\mathrm{N}$-deposition, habitat fragmentation, and climate change (Chazdon 2008; Kariyawasam et al. 2021). Moreover, the forest restoration is inextricably associated with levels of land or soil degradation, biodiversity erosion, residual vegetation, and desired restoration outcomes (Fig. 5). Henceforth, all these factors should be taken into consideration for achieving sustainable ecosystem restoration. Especially, in 
perspective of growing or the lower-middle income economies such as India the National Mission on Biodiversity and Human Well-Being (NMBHWB) aimed to preserve as well as restore biodiversity (Bawa et al. 2021; Banerjee et al. 2021). Elucidating the future distribution of IAPs such as Cecropia peltata and Ulex europaeus through ecological niche models can be vital in their containment as well as environmental restoration (Gong et al. 2020). In this context, the effects of climate change on IAPs can be dependent on environmental scenario and IAP-specific attributes (Gong et al. 2020). Henceforth, under the umbrella of biodiversity conservation multiple aspects (e.g., livelihood, human well-being, ecosystem services, climate change, agriculture, health, and bio-/circular economy) need to be addressed in an integrated framework for sustainably managing the plant invaders.

\section{Ecosystem Services and Socio-Economic/ Livelihood Impacts of IAPs Invasion}

Certain IAPs may be useful in terms of ecosystem services and associated socio-economic or livelihood co-benefits. Several IAPs can also modulate the nutrient levels and hence augment the soil fertility in agroecosystems, as evidenced through colonization of cheatgrass (B. tectorum) in association with cyanobacterial consortium (Ferrenberg et al. 2018). Further, soil amendment with L camara biomass was demonstrated to improve soil hydraulic properties which increased the wheat productivity in a rice-wheat cropping sequence (Bhushan and Sharma 2005). Another IAP, $F$. japonica (Japanese knotweed) has shown its adaptability to survive in habitat stressed with salinity, thus can be used in short-term land rehabilitation strategies (Rouifed et al. 2012). It has been well known that mutualistic association of microbial diversity (e.g. of AMF) with higher plants can assists in the sustenance of healthy forest ecosystems (Kumar et al. 2021). In this sense, a few plant invaders have also been reported to promote the diversity of AMF in Hawaii forests (Gomes et al. 2018). In this respect, IAPs such as C. stoebe and E. esula enhanced the colonization of mycorrhizal fungi which can find implications in ecosystem restoration (Lekberg et al. 2013). Also invasive alien plants regulate biogeochemical nutrient cycling (by enriching the soil with better nutrient allocation and carbon sequestration) and food webs (by their role as food crops/medicinal importance) (Rai 2017a). Some IAP such as A. adenophora acted as invasion corridor to facilitate the entry of other IAPs such as Eucalyptus in agroecosystems, which is actually mediated through alterations of soil physico-chemical characteristics (Yu et al. 2014). Conversely, certain IAPs (e.g., Mesembryanthemum crystallinum, and Tamarix spp.) prevented the entry of other IAPs by enhancing the soil salinity (El-Ghareeb 1991; Zavaleta et al. 2001). Therefore, the option of IAPs in restoration projects can be species and site-specific to help maintain the environmental sustainability.

Aquatic IAP such as Phragmites sp. (Giant reed), rated among 100 worst global invaders (Lowe et al. 2000), has got applications in the polymer industry owing to its rich lignocellulosic biomass (Fiore et al. 2014). Another study noted that the use of Giant reed in soil/sludge amendment which can enhance the agricultural productivity (Pelegrín et al. 2018). Several IAPs augment to the sustainable ecosystem restoration by offering several co-benefits such as bio-energy, animal feed, bio-polymers, and in augmenting the green economy (Edrisi and Abhilash 2015; Rai and Kim 2020). In this aspect Edrisi et al. (2020) also described various community livelihood benefits, ecosystem services, and co-benefits in the form of bioenergy of an IAP Prosopis juliflora. Nevertheless, Edrisi et al. (2020) opined the judicial use of multi-purpose IAPs in ecosystem restoration due to their possible adverse impacts on native diversity, soil microbial community, and livelihood uses of native fodder/ food crops.

Several attribute of IAPs can be treated as vital ecosystem services. In this aspect, 'Nurse Plant' (shielding the plantations against heat and solar radiation), providing the physical structure (perches) for pollinators (e.g., birds and bats) which are useful in seed recruitment, acting as provision fuel for controlled fire to reshape vegetation, safeguarding or securing the site against further biotic invasions, maintaining healthy trophic relationships, biogeochemical services, and bio-agents for phytoremediation (Ewel and Putz 2004; Rai et al. 2020) are beneficial prospects of IAPs. Nonetheless, there are several challanges (e.g., issue of ecological economics, long-term effects, and reversibility aspects) which complicate the utility of IAPs in restoration. In highly disturbed ecosystems, where IAP acted as 'transformer species'/drivers (Richardson et al. 2000), the traditional weed management strategies can be impractical and may end up in an un-sustainable restoration (MacDougall and Turkington 2005; Hastings et al. 2007). Therefore, Reid et al. (2009) opined that IAPs management strategies for eco-restoration can be sustainable only in moderately disturbed landscapes. There has been great debate on the use or role of IAPs in ecosystem restoration. The divided opinion on the utilization of IAPs in the restoration of degraded environment are either in terms of threat (adverse effects) or utility (IAPs associated positive co-benefits). The origin of this different school of thought lies in the fact that a group of restoration ecologists advocated that all IAPs should not be considered as a nuisance in totality (Ewel and Putz 2004). This IAPs advocacy was based on fact that in certain cases the IAPs management strategies for the restoration of degraded environment were either reversible or economically infeasible. 
This was exemplified in a case study on IAPs $M$. quinquenervia (melaleuca tree; 3-6 million USD) and Hydrilla verticillata (hydrilla; 14.5 million USD) (Pimentel et al. 2005; Reid et al. 2009). Accordingly, Ewel and Putz (2004) therefore countered the blanked condemnation of IAPs in restoration strategies and advocated their judicial use in view of their co-benefits in terms of ecological and socio-economic payoffs.

Several studies revealed that the long-term use of IAPs in restoration projects can be hazardous to the environment. The use of IAPs (e.g., M. mikrantha and C. odorata) in restoration of degraded jhumlands initially played a vital role in preventing the soil as well as nutrients run-off (Toky and Ramakrishnan 1983). Considering the traditional practice of un-regulated shifting cultivation, M. mikrantha was able to enrich nutrients, especially potassium (K) in aboveground biomass, thereby assisting in restoration of degraded environment (Saxena and Ramakrishnan 1983; Swamy and Ramakrishnan 1987; Rai 2017b). Nevertheless, in shortened jhum cycle, the 'arrested forest succession' and incomplete restoration of soil fertility was noted to reduce the agricultural productivity (Toky and Ramakrishnan 1983; Rai 2017b). Concomitantly, the long-term heavy infestation of M. mikrantha can reduce the native biodiversity and soil fertility which can eventually lead to desertification of invaded site (Ramakrishnan 2017). Another study by Li et al. (2015) revealed that indigenous native plants (Cupressus torulosa and Pinus yunnanensis) were more effective in restoration of soil N/microbial biomass when compared with an IAP (Eucalyptus globulus). In addition, Mikania mikrantha (mile a minute weed) was introduced as cover crop in an Indo-Burma hotspot region (NE India) to mitigate the soil erosion in tea gardens however, several socio-ecological concerns aroused after its landscape spread (Ramakrishnan 2017). Likewise, Edrisi et al. (2020) also noted a decrease in belowground microbial biomass and number of native plants in Prosopis juliflora invaded degraded land, when compared with non-invaded patches. Hence, a group of ecologists demonstrated the adverse effects of IAPs in restoration of degraded environment.

\section{Traditional Ecological Knowledge (TEK) in IAPs Management and Ecosystem Restoration}

In restoration programmes of IAPs, the local community participation and judicially utilizing their indigenous or traditional ecological knowledge (TEK) on the ecological/economic aspects of planted trees or food crops can be of paramount importance (Chokkalingam et al. 2005; Zavaleta-Cortijo et al. 2020). In restoration perspectives of plant invaders, incorporation of TEK in biodiversity rich regions can help in achieving environmental sustainability and rural livelihood. Nevertheless, the recent Coronavirus pandemic adversely influenced the IAP risks assessment studies, TEK, and livelihood /food security options of poor people (Zavaleta-Cortijo et al. 2020).

In past studies, TEK was successfully implemented in the restoration of several IAP invaded global landscapes such as Amazon River basin, Indonesia, Peru, Indo Burma hotspot region, and Philippines (Chokkalingam et al. 2005; Rai and Singh 2021). Further, the implementation of traditional pastoralist practice under HASHI (Hifadhi Ardhi Shinyanga as Swahili acronym which denotes Shinyanga Soil Conservation programme in northwest Tanzania, operated during 1986-2004) remarkably assisted in restoration of 350,000 ha of Acacia and Miombo woodland which benefitted local people from 833 villages, in moderate time interval of 18 years (Monela 2004). Shifting cultivation Jhoom is an ethnoagricuture practice in certain regions, closely linked with TEK, socio-cultural life and livelihood of the traditional indigenous people (Ramakrishnan 1993; Ramakrishnan 2017; Rai 2017b). During past decades shifting cultivation (with jhum cycle of 20-30 years) was supposed to be a sustainable use of forest ecosystems as cultivators had plenty of forest areas available (Ramakrishnan 2001). However, in recent times, this ethnoagriculture practice accounted for about $61 \%$ of total tropical forest destruction, decline in faunal diversity, and makes the degraded land surface ripe for IAPs infestation (Raman 2001; Rai 2012). Furthermore, due to expanding population, the area under forested landscapes rapidly declined, therefore fallow period became drastically reduced to 4-5 years, resulting in serious soil erosion and decline in the soil's fertility and productivity (Ramakrishnan 2001). The tropical forests which are extremely fragile due to its highly leached soil and tight nutrient cycling (via a surface root mat) are particularly sensitive to unregulated shifting cultivation and IAPs colonization (Ramakrishnan 2017; Rai and Singh 2021).

The reduced fallow period of 4-5 years in shifting cultivation was observed to be more prone to infestation of IAPs such as $M$. mikrantha and $C$. odorata, than those following regulated time frame of 30 years (Ramakrishnan 2017). Herein, IAPs acted as passengers along with the environmental disturbances imposed through unregulated shifting cultivation. To elucidate the geographical horizon of this ethnoagricuture practice in NE India, Landsat- 8 data (2014-2018) revealed that Manipur state had highest shifting cultivated land with a fallow area of $1528.5 \mathrm{~km}^{2}$ while Tripura recorded lowest i.e., $178.3 \mathrm{~km}^{2}$ (Pasha et al. 2020). To this end, Pasha et al. (2020) noted the dominance of four IAPs (M. micrantha, Ageratum houstonianum, and C. odorata and $A$. adenophora) in fallow lands under shifting cultivation. Furthermore, shifting cultivation fallow hotspot map was designed to delineate the repetitive patches in NE India 
and such patches were noted highest in Arunachal Pradesh (24.9\%) while lowest in Tripura (3.6\%) (Pasha et al. 2020). These disturbed patches can pave the way to introduction and successful colonization of plant invaders.

Several studies in traditional landscapes noted that IAPs initially acted as passengers along the disturbance gradients and later became the drivers of environmental degradation (Saxena and Ramakrishnan 1983; Sakachep and Rai 2021; Vanlalruati and Rai 2021). The population dynamics of IAP like M. micrantha (Swamy and Ramakrishnan 1987) and Eupatorium odoratum (now C. odorata) (Kushwaha et al. 1981) were investigated under the event of shifting cultivation. Interestingly, it was observed that this ethnoagricultural practice facilitated the recruitment of IAPs at the shifting cultivated site in view of larger seed bank, when compared to other land-use (e.g., terrace agriculture) (Rai 2017b). In this sense, Swamy and Ramakrishnan (1987) observed that invasive spread of M. mikrantha in shortcycled jhum systems was remarkably facilitated by burning or fire. As discussed earlier in the present article, M. micrantha and C. odorata can be associated with several pros as well as cons in ecosystem restoration perspective of jhumlands (Fig. 6). Figure 6 represents the patch of degraded land invaded with Parthenium hysterophorus (Fig. 6A) and heavy infestation of M. micrantha (Fig. 6B) in Mizoram, NE India.

Unregulated shifting cultivation has therefore perturbed the pristine ecology, forest diversity, and caused IAPs induced environmental degradation in in traditional landscapes (Ramakrishnan 2017). Shifting cultivation and deforestation are major constraints in developing sustainable food-production systems in the traditional landscapes (Rai 2012; Bawa et al. 2021). Moreover, in urban areas of high demographic growth and increasing land shortages, intensification of slash and burn system can be highly detrimental and make the sites prone to infestation of IAPs (Rai and Singh 2020a, b). Intensified land use under shifting cultivation not only increase IAPs infestation but also shift in the species composition, as demonstrated through the dominance of bamboo species (Rai 2009; Banerjee et al. 2021). Therefore, Food and Agricultural Organisation (FAO) in 1957 officially condemned shifting cultivation due to major cause of IAPs infestation, soil erosion, land degradation, and deforestation (Rai 2017b).

In biodiversity-rich countries, traditional landscapes, and global protected areas, the concept of 'hybrid technologies' can be incorporated in the implementation of IAPs restoration strategies to help attain the holistic environmental sustainability (Ramakrishnan 2017). Herein, hybrid technologies can be pragmatic integration of formal science or knowledge-based technologies (e.g., biorefinery) with TEK practiced by indigenous community. In this context, TEK can be further segregated into (a) Economic TEK related to the use of traditional wild crop varieties and ethno- medicinal plants (Rai and Lalramnghinghlova 2011a, b; Rai 2017a; Feng et al. 2021); (b) ecological/social TEK involves judicial use of biodiversity for enhancing the environmental reliance towards various environmental disturbances and restoring soil fertility, and (c) ethical TEK aims to revitalize the sociocultural, religious, and spiritual aspects through the evolution of sacred species and landscapes (Ramakrishnan 2017).

The modern scientific approaches (e.g., biorefinery, biopharmacy, phytoremediation, phytochemistry, eco-friendly innovations in agro-biotechnologies, nano-science, carbon dioxide removal technologies, solar geoengineering, in situ genetically modified organisms, gene drive organisms, deextinction, and high-tech ecosystem restoration) are advocated to address the problem of biodiversity depletion and climate change (Rai et al. 2018; Rai 2019; Reynolds 2021). The TEK (e.g. Sacred groves based on religious sentiments, Apatanis agricultural practice of integrated wet rice cultivation in an Indo-Burma hot spot region, indigenous water harvesting eco-technologies, ethno-medicinal plants in primary health care, and sustainable agroforestry with keystone species of socio-economic importance) can also assist in ecosystem restoration of invaded landscapes (Ramakrishnan 2001; Rai 2012; Reynolds 2021). Incorporating TEK-based technologies in the restoration of IAPs invaded regions can assist in selection of plantation species which are of socio-cultural, ecological, environmental, and socioeconomic importance (Rai, 2012, 2013; Feng et al. 2021). In this aspect, Ramakrishnan (2017) identified several ecological keystone plants such as Alnus nepalensis (Nepalese alder), Quercus spp. (Oaks), Ficus spp, and several bamboo species which were of paramount importance in restoring the degraded shifting cultivated lands. Among these plants, Nepalese alder can potentially conserve $125 \mathrm{~kg} \mathrm{~N} / \mathrm{ha}$ annually in degraded jhumlands and thus can be used in restoration projects (Ramakrishnan 1993). Therefore potential screening of appropriate plants with respect to the TEK, biorefinery co-benefits, and socio-cultural/socio-economic aspects of local people can aid in sustainable ecosystem restoration of IAPs invaded landscapes (Rai 2012, 2021; Feng et al. 2021; Syed et al. 2021). Thus, judicial adoption of IAPs management strategies can be practiced in cultural landscapes, to help attain the sustainable restoration of IAPs and rural livelihood.

\section{Sustainability Considerations in the Restoration of IAPs Invaded Ecosystem: Future Prospects}

In IAPs management and ecosystem restoration, sustainability paradigm can be driven by multiple factors (e.g., the soil-type/cover, habitat fragmentation, and dispersal) (Bauer and Reynolds 2016; Gornish and dos Santos 2016; 
Fig. 6 Environmental degradation and potential IAPs induced ecosystem/land degradation in the infested region. (A) Parthenium hysterophorus $\mathrm{L}$. menace in Varanasi, a sacred Indian landscape (Photo courtesy: Mr. Krishna Kumar Pandey, IESD, BHU, Varanasi) and (B) Heavy infestation of Mikania micrantha Kunth in fallow lands of Mizoram, NE India (Photo courtesy: PK Rai)
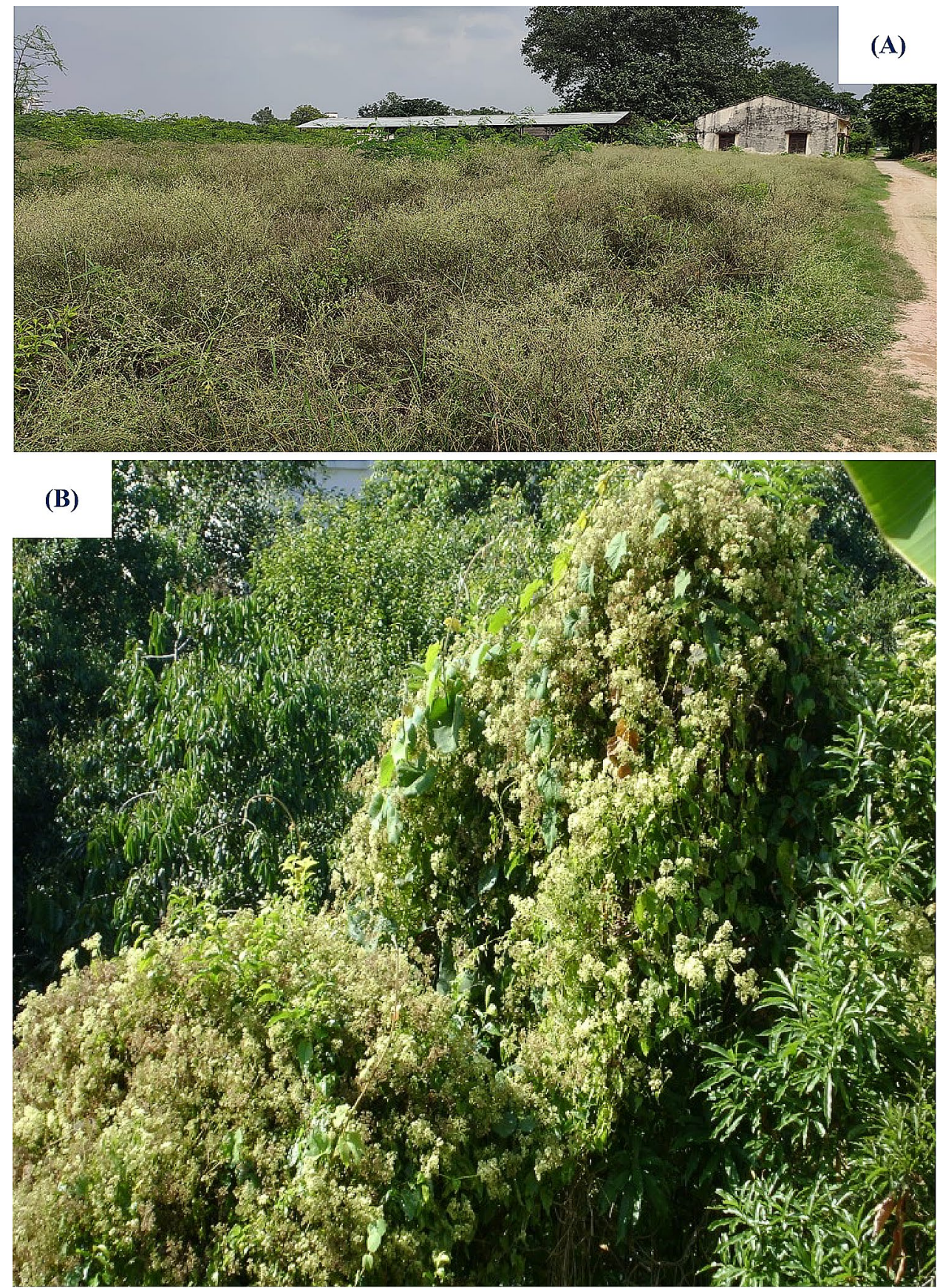

Gao et al. 2020; Shiferaw 2021; García-díaz et al. 2021). In this sense, Priyadarshini and Abhilash (2020) opined that implementation of environmental restoration strategies in concert with the incorporation of circularity practices, such as biorefinery co-benefits (e.g., bioenergy/bio-fuel production) to provide an impetus in achieving the several targets of SDGs. Furthermore, the clean energy production through potential bioenergy non-food crops (e.g., Panicum virgatum and Brassica carinata) on degraded or marginal non-arable lands can enhance the C-sequestration, energy security, provisioning services, rural livelihood, and, assist in climate change mitigation without compromising the food security (Priyadarshini and Abhilash 2020; Abhilash 2021; Feng et al. 2021).

Circular bioeconomy emphasizes the use of renewable bioresources for the human needs such as materials, food, and energy (Woźniak et al. 2021). In this sense, several IAPs act as potential bioresource and can contribute to circular economy (Feng et al. 2021). The basic principles of circular economy (e.g., reduction, recycling, recovery, and resource efficiency) are inextricably linked with ecosystem services. The judicial application of the circularity in replenishing 
the ecosystem services (e.g., provisioning, regulating, and cultural services) can help achieving the SDG 2, 6, 7, 8, 10, 12, 13, and 15 (Priyadarshini and Abhilash 2020). To this end, several IAPs such as Spartina alterniflora can engineer the soil attributes with concomitant applications to biorefinery prospects and circular economy (Syed et al. 2021). In addition, the pyrolysis of IAP feedstocks for biochar production is a potential biorefinery approach to augment the circular economy (Feng et al. 2021). These approaches in totality address the economic considerations and financial incentives involved in restoration projects of IAPs invaded regions. However, the on-going COVID-19 pandemic also impeded the global progress in the use of IAPs in circular bioeconomy and biorefinery prospects (Zavaleta-Cortijo et al. 2020; Woźniak et al. 2021).

In respect of sustainable IAPs mitigation, several global Institutions such as Scientific Committee on Problems of the Environment (SCOPE), GISP (Global Invasive Species Program), CABI (Centre for Agriculture and Bioscience International), and UN-IPBES (Intergovernmental SciencePolicy Platform on Biodiversity and Ecosystem Services) are enforcing legal regulatory measures for biodiversity restoration. In this respect, UN-IPBES-global indicators target (i.e., 15.8) aimed to achieve SDGs through implementation of effective management strategies to control the IAPs by 2020 (IPBES 2019a, b; McGeoch and Jetz 2019; Rai and Singh 2021). Especially, in relation to IAPs management, CBD adopted Aichi Biodiversity Target 9 to effectively restore and revitalize the ecosystem services (Egoh et al. 2020). In this aspect, UNCCD advocated the adoption of land degradation neutrality (LDN) as a solution to stop further environmental degradation and concomitantly revitalize various ecosystem services and livelihood prospects. In additon, LDN was also intimately linked with the attainment SDG 15.3 target (Chapman and Tsuji 2020). Conversely, IAPs were considered to be a major challenge in achieving SDG targets, especially in the context of lands (Paulvon et al. 2019) (Fig. 2). Furthermore, the environmentally sustainable land restoration strategies are an integral doctrine of United Nations Decade of Ecosystem Restoration (UN-DER, 2021-2030) which was adapted and resolved in 73rd session of UN Assembly. Nonetheless, the COVID-19 pandemic further impeded the prospects of attaining the SDGs in the given time framework (Chapman and Tsuji 2020).

Under the existing regulatory measures of IAPs, UNSDG 15.8 (to "reduce the impact of IAPs on land and water ecosystems and control or eradicate the priority species.") emphasize their management to sustain the land biodiversity. Further, the CBD also prioritized to mitigate the adverse effects of IAPs (e.g., through "Zero Draft of the Post-2020 Global Biodiversity Framework") (CBD 2020). Notably, the action target 3 of CBD states to "control IAPs to eliminate or reduce their impacts by
2030 in at least (50\%) of priority sites". Therefore, the past research studies and regulatory measures of IAPs prioritized the need for impact-based long-term management (García-díaz et al. 2021). In this sense, efforts to mitigate the adverse impacts of biotic invaders are prioritized as sustainable strategy in long-term which can be difficult to attain with species-specific approach. In addition, protected areas and global biodiversity hotspots should be given special attention to minimize the adverse impacts of IAPs on environment and ecosystem services (Rai and Singh 2021). Due to the high risks of IAPs, biosecurity regulations should be tightly regulated at a global scale as 'National biosecurity programs' such as Australia and New Zealand (Pyšek et al. 2020). In relation to environment and biodiversity restoration, strict trading regulations with concrete biosecurity framework and implementing focused holistic legal measures in perspective of IAPs are required (Banerjee et al. 2021). In addition, classical control can be abridged with recent biotechnological advances (e.g., CRISPR-Cas9 (clustered regularly interspaced short palindromic repeats), gene-editing technology, and omics) in quest of effective IAPs management (Rai et al. 2020).

In biodiversity-rich nations with a growing economy, the IAPs management is faced with several challenges such as poor decision support systems/response capacities, inadequate collaboration among stakeholders, huge dependency on bioresources, and lack of people participation (Banerjee et al. 2021). There exists a dearth of studies which empirically investigate the synergies of IAPs spread with other anthropogenic disturbances under the event of climate change (Pyšek et al. 2020). Henceforth, the ecological investigation of this synergy in IAPs success can provide an impetus to their sustainable management. In assessing the effects of IAPs (e.g., Salvia rosmarinus, Eucalyptus globulus, and Acacia saligna) on environment the trait-environment modelling approach can inventory the high-risk plant invaders, whereas SDMs can assist in the prioritization of habitats prone to infestation (ElBarougy et al. 2021). Hulme (2021) opined that the current scientific studies and institutional/legislative measures to manage the global biotic invaders are inadequate and warrant empirical researches in a future perspective. Moreover, the lockdowns during COVID-19 pandemic revealed both positive and negative short-term effects on the spread of biotic invaders (Parrino et al. 2021). These effects were ascribed to decreased human disturbances and altered Man-Environment interactions. However, longterm effects of COVID-19 induced lockdowns need to be assessed in future studies with sustainable action for IAPs management and possible environmental amelioration (Bouman et al. 2021; Parrino et al. 2021). 


\section{Conclusions}

In the Anthropocene, IAPs acted as passengers along with the multiple environmental disturbances. The adverse impacts of IAPs on biodiversity, water, and soil resources acted as drivers of environmental degradation. In the present scenario, the COVID-19 pandemic has remarkably influenced the IAPs research and environmental sustainability. The IAPs driven effects on soil physico-chemical and biological characteristics remarkably jeopardized the health of global ecosystems. For sustainable restoration of IAPs invaded environment, abiotic/biotic components need to be revitalized in totality. In addition, the restoration of IAPs infested ecosystems needs to be prioritized as inextricably linked with attainment of various SDGs (e.g., SDG 2, 6, 7, 8, 10, 12, 13, and 15). Though blanket condemnation of IAPs in ecosystem restoration is not advised in several studies due to multiple co-benefits however, the use of IAPs in ecological restoration needs pragmatic evaluation of ecological economics and long-term ecosystem effects. To this end, the incorporation of hybrid technologies (which integrate acquired scientific information and TEK) in restoration efforts can augment the environmental sustainability and rural livelihood prospects of indigenous people. The success stories of hybrid technologies and sustainable restoration strategies in the containment of IAPs should be extrapolated in other landscapes to mitigate the environmental degradation. Last, the holistic approach in the restoration of the degraded environment in concert with the circular economy can remarkably influence in attaining the target of UN-SDGs and UN-DER (2021-30).

Acknowledgements PKR is thankful to Dr. P.C. Abhilash, IESD, BHU and Editor in Chief of Anthropocene Science for his kind invitation and valuable suggestions to upgrade this review. Author also acknowledges the Department of Biotechnology (DBT) and Department of Science and Technology (DST) for financial assistance vide project no.BT/PR24917/NER/95/907/2017and.DST/TMD/EWO/WTI/2K19/ EWFH/2019 (C), respectively. The author is also thankful to Professor J.S. Singh for his guidance and valuable suggestions.

\section{Declarations}

Conflict of interest Author declares that there is no conflict of interest in relation to contents of this article.

\section{References}

Abhilash PC (2021) Restoring the unrestored: strategies for restoring global land during the UN-Decade on Ecosystem Restoration (UN-DER). Land 10:201. https://doi.org/10.3390/land100202 01

Abhilash PC, Bastianoni S, Chen W et al (2021) Introducing 'Anthropocene Science': a new international journal for addressing human impact on the resilience of planet Earth. Anthr Sci (in Press). https://doi.org/10.1007/s44177-021-00001-1

Acharya BS et al (2018) Woody plant encroachment impacts on groundwater recharge: a review. Water 10:1466. https://doi. org/10.3390/w10101466

Allen WJ et al (2021) Exotic plants accumulate and share herbivores yet dominate communities via rapid growth. Nat Commun 12:2696. https://doi.org/10.1038/s41467-021-23030-1

Aragón R et al (2014) Exotic species as modifiers of ecosystem processes: Litter decomposition in native and invaded secondary forests of NW Argentina. Acta Oecol 54:21-28. https://doi.org/ 10.1016/j.actao.2013.03.007

Banerjee AK et al (2021) An integrated policy framework and plan of action to prevent and control plant invasions in India. Environ Sci Policy 124:64-72. https://doi.org/10.1016/j.envsci. 2021.06.003

Bargali SS, Singh RP, Joshi M (1993) Changes in soil characteristics in eucalyptus plantations replacing natural broad-leaved forests. J Veg Sci 4:25-28. https://doi.org/10.2307/3235730

Bauer JT, Reynolds HL (2016) Restoring native understory to a woodland invaded by Euonymus fortunei: multiple factors affect success. Restor Ecol 24:42-52. https://doi.org/10.1111/ rec. 12285

Bawa KS et al (2021) Securing biodiversity, securing our future: A national mission on biodiversity and human well-being for India. Biol Conserv 253:108867. https://doi.org/10.1016/j.biocon.2020. 108867

Belnap J, Phillips SL (2001) Soil biota in an ungrazed grassland: response to annual grass (Bromus tectorum) invasion. Ecol Appl 11:1261-1275. https://doi.org/10.1890/1051-0761(2001) 011[1261:SBIAUG]2.0.CO;2

Bhushan L, Sharma PK (2005) Long-term effects of lantana residue additions on water retention and transmission properties of a medium-textured soil under rice-wheat cropping in northwest India. Soil Use Manage 21:32-37. https://doi.org/10.1111/j. 1475-2743.2005.tb00104.x

Blumenthal DM (2006) Interactions between resource availability and enemy release in plant invasion. Ecol Lett 9:887-895. https://doi. org/10.1111/j.1461-0248.2006.00934.x

Blumenthal DM et al (2016) Cheatgrass is favored by warming but not $\mathrm{CO}_{2}$ enrichment in semi-arid grassland. Glob Chang Biol 22:3026-3038. https://doi.org/10.1111/gcb.13278

Bolpagni R (2021) Towards global dominance of invasive alien plants in freshwater ecosystems: the dawn of the Exocene? Hydrobiologia 848:2259-2279. https://doi.org/10.1007/s10750-02004490-w(0123456789

Boon PI et al (1997) Organic matter decay in coastal wetlands: An inhibitory role for essential oil from Melaleuca quinquenervia. Arch Hydrobiol 138:438-439. https://doi.org/10.1127/00039136/2003/0156-0225

Bouman T, Steg L, Dietz T (2021) Insights from early COVID-19 responses about promoting sustainable action. Nat Sustain 4:194-200. https://doi.org/10.1038/s41893-020-00626-x

Callaway RM et al (2004) Soil biota and exotic plant invasion. Nature 427:731. https://doi.org/10.1038/nature02322

Caravaca FJ et al (2003) Establishment of shrub species in a degraded semiarid site after inoculations with native allocthonous arbuscular mycorrhizal fungi. Appl Ecol 22:103-111. https://doi.org/ 10.1016/S0929-1393(02)00136-1

Chapin FS III (2003) Effects of plant traits on ecosystem and regional processes: a conceptual framework for predicting the consequences of global change. Ann Bot 91:455-463. https://doi.org/ 10.1093/aob/mcg041

Chapman A, Tsuji T (2020) Impacts of COVID-19 on a transitioning energy system, society, and international cooperation. Sustainability 12:8232. https://doi.org/10.3390/su12198232 
Chazdon RL (2008) Beyond deforestation: Restoring forests and ecosystem services on degraded lands. Science 320:1458-1460. https://doi.org/10.1126/science. 1155365

Chokkalingam U et al. (2005) In forest restoration in landscapes: beyond planting trees. In: Mansourian S, Vallauri D, Dudley N (eds). Springer, New York, pp 405-414 (ISBN 978-0-387-29112-3)

Crisp N (2021) Human flourishing in a health-creating society. Lancet 397:P1054-1055. https://doi.org/10.1016/S0140-6736(21) 00585-7

Cuthbert RN et al (2021) Global economic costs of aquatic invasive alien species. Sci Total Environ 775:145238. https://doi.org/ 10.1016/j.scitotenv.2021.145238

Dassonville $\mathrm{N}$ et al (2008) Impacts of alien invasive plants on soil nutrients are correlated with initial site conditions in NW Europe. Oecologia 157:131-140. https://doi.org/10.1007/ s00442-008-1054-6

Díaz S, Zafra-Calvo N, Purvis A, Verburg PH et al (2020) Set ambitious goals for biodiversity and sustainability. Science 370:411-413. https://doi.org/10.1126/science.abe1530

Doerr SH, Shakesby RA, Walsh RPD (2000) Soil water repellency: its causes, characteristics and hydro-geomorphological significance. Earth Sci Rev 51:33-65. https://doi.org/10.1016/ S0012-8252(00)00011-8

Dudley BD, Hughes R, Ostertag R (2014) Groundwater availability mediates the ecosystem effects of an invasion of Prosopis pallida. Ecol Appl 24:1954-1971. https://doi.org/10.1890/ $13-1262.1$

Dzikiti S et al (2017) Assessing water use by Prosopis invasions and Vachellia karroo trees: implications for groundwater recovery following alien plant removal in an arid catchment in South Africa. For Ecol Manag 398:153-163. https://doi.org/10.1016/j. foreco.2017.05.009

Early R, Bradley BA, Dukes JS et al (2016) Global threats from invasive alien species in the twenty-first century and national response capacities. Nat Commun 7:12485. https://doi.org/10. 1038/ncomms 12485

Edrisi SA, Abhilash PC (2015) Sustainable bioenergy production from woody biomass: prospects and promises. J Clean Prod 102:558559. https://doi.org/10.1016/j.jclepro.2015.04.031

Edrisi SA, El-Keblawy A, Abhilash PC (2020) Sustainability analysis of Prosopis juliflora (Sw.) DC based restoration of degraded land in North India. Land 9:59. https://doi.org/10.3390/land9020059

Egoh BN et al (2020) Setting the scene for achievable post-2020 convention on biological diversity targets: a review of the impacts of invasive alien species on ecosystem services in Africa. J Environ Manage 261:110171. https://doi.org/10.1016/j.jenvman.2020. 110171

Ehrenfeld JG (2003) Effects of exotic plant invasions on soil nutrient cycling processes. Ecosystems 6:503-523. https://doi.org/10. 1007/s10021-002-0151-3

El-Barougy $\mathrm{F}$ et al (2021) Invasion risk assessment using trait-environment and species distribution modelling techniques in an arid protected area: Towards conservation prioritization. Ecol Ind 129:107951. https://doi.org/10.1016/j.ecolind.2021.107951

El-Ghareeb R (1991) Vegetation and soil changes induced by Mesembryanthemum crystallinum L. in a Mediterranean desert ecosystem. J Arid Environ 20:321-330. https://doi.org/10.1016/ S0140-1963(18)30693-1

Elton CS (1958) The ecology of invasions by animals and plants. Methuen, London

Eviner VT (2004) Plant species have unique combinations of traits that influence ecosystem processes. Ecology 85:2215-2229. https:// doi.org/10.1890/03-0405

Eviner VT, Chapin FS III (2003) Functional matrix: a conceptual framework for predicting multiple plant effects on ecosystem processes. Annu Rev Ecol Syst 34:455-485. https://doi.org/10. 1146/annurev.ecolsys.34.011802.132342

Eviner VT, Hawkes CV (2008) Embracing variability in the application of plant-soil interactions to the restoration of communities and ecosystems. Restor Ecol 16:713-729. https://doi.org/10.1111/j. 1526-100X.2008.00482.x

Ewel JJ, Putz FE (2004) A place for alien species in ecosystem restoration. Front Ecol Environ 2:354-360. https://doi.org/10.1890/ 1540-9295(2004)002[0354:APFASI]2.0.CO;2

Ewel KC et al (2001) Managing critical transition zones. Ecosystems 4:452-460. https://doi.org/10.1007/s10021-001-0106-0

Fabbro CD, Prati D (2015) The relative importance of immediate allelopathy and allelopathic legacy in invasive plant species. Basic Appl Ecol 16:28-35. https://doi.org/10.1016/j.baae.2014.10.007

FAO (2005) Global Forest Resources Assessment. Progress towards sustainable forest management. Food and Agricultural Organization of the United Nation, Rome. Accessed 14th Jan 2021

FAO (2006) Guidelines on food fortification with micronutrients. Food and Agricultural Organization of the United Nation, Rome, Italy. https://www.who.int/nutrition/publications/micronutrients/92415 94012/en/. Accessed 14th Mar 2021

FAO (2019) Database on Introductions of Aquatic Species (DIAS). FAO Fisheries and Aquaculture Department, Food and Agricultural Organization of the United Nation, Rome. http://www.fao. org/fishery/topic/14786/en

Feng Q et al (2021) Invasive plants as potential sustainable feedstocks for biochar production and multiple applications: a review. Resour Cons Recycl 164:105204. https://doi.org/10.1016/j.resco nrec.2020.105204

Ferrenberg S et al (2018) Biocrusts enhance soil fertility and Bromus tectorum growth, and interact with warming to influence germination. Plant Soil 429(1-2):77-90. https://doi.org/10.1007/ s11104-017-3525-1

Fiore V, Scalici T, Valenza A (2014) Characterization of a new natural fiber from Arundo donax L. as potential reinforcement of polymer composites. Carbohydr Polym 106:77-83. https://doi.org/ 10.1016/j.carbpol.2014.02.016

Foxcroft LC, Henderson L, Nichols GR, Martin BW (2003) A revised list of alien plants for the Kruger National Park. Koedoe 46:2144. https://doi.org/10.4102/koedoe.v46i2.54

Fukano Y, Tachiki Y, Yahara T, Iwasa Y (2013) Soil disturbances can supress the invasion of alien plants under plant-soil feedback. Ecol Modell 260:42-49

Funk JF (2008) Differences in plasticity between invasive and native plants from a low resource environment. J Ecol 96:1162-1173. https://doi.org/10.1016/j.ecolmodel.2013.03.022

Gaertner M, Nottebrock H, Fourie H, Privett SDJ, Richardson DM (2012) Plant invasions, restoration, and economics: perspectives from South African fynbos. Plant Ecol Evol Syst 14:341-353. https://doi.org/10.1016/j.ppees.2012.05.001

Gaertner M, Biggs R, Te Beest M, Hui C, Molofsky J, Richardson DM (2014) Invasive plants as drivers of regime shifts: identifying high-priority invaders that alter feedback relationships. Divers Distrib 20:733-744. https://doi.org/10.1111/ddi.12182

Gaggini L, Rusterholz H, Baur B (2018) The invasive plant Impatiens glandulifera affects soil fungal diversity and the bacterial community in forests. Appl Soil Ecol 124:335-343. https://doi.org/ 10.1016/j.apsoil.2017.11.021

Gao F et al (2020) Effects of soil nutrient heterogeneity on the growth and invasion success of alien plants:a multi-species study. Front Ecol Evol 8:619861. https://doi.org/10.3389/fevo.2020.619861

García-díaz P et al (2021) Management policies for invasive alien species: addressing the impacts rather than the species. Bioscience 71:174-185. https://doi.org/10.1093/biosci/biaa139 
Gibbons SM et al (2017) Invasive plants rapidly reshape soil properties in a grassland ecosystem. mSystems 2:e00178-e216. https://doi. org/10.1128/mSystems.00178-16

Gioria M, Pyšek P (2016) The legacy of plant invasions: Changes in the soil seed bank of invaded plant communities. Bioscience 66:40-53. https://doi.org/10.1093/biosci/biv165

Gomes SIF et al (2018) Biological invasions increase the richness of arbuscular mycorrhizal fungi from a Hawaiian subtropical ecosystem. Biol Invasions 20:2421-2437. https://doi.org/10.1007/ s10530-018-1710-7

Gong X et al (2020) Double-edged effects of climate change on plant invasions: Ecological niche modeling global distributions of two invasive alien plants. Sci Total Environ 740:139933. https://doi. org/10.1016/j.scitotenv.2020.139933

Gornish ES, dos Santos PA (2016) Invasive species cover, soil type, and grazing interact to predict long-term grassland restoration success. Restor Ecol 24:222-229. https://doi.org/10.1111/rec. 12308

Goslee SC, Peters DPC, Beck KG (2001) Modeling invasive weeds in grasslands: the role of allelopathy in Acroptilon repens invasion. Ecol Modell 139:31-45. https://doi.org/10.1016/S0304-3800(01) 00231-9

Graf WL (1978) Fluvial adjustments to the spread of tamarisk in the Colorado Plateau region. Geol Soc Am Bull 89:1491-1501. https://doi.org/10.1130/0016-7606(1979)90\%3c1183:FATTSA\% 3e2.0.CO;2

Greenway M (1994) Litter accession and accumulation in a Melaleuca quinquenervia (Cav.) S.T. Blake wetland in south-eastern Queensland. Aust J Mar Freshw Res 45:1509-1519. https://doi. org/10.1071/MF9941509

Greenwood P et al (2018) The invasive alien plant, Impatiens glandulifera (Himalayan Balsam), and increased soil erosion: causation or association? Case studies from a river system in Switzerland and the UK. J Soils Sediments 18:3463-3477. https://doi.org/10. 1007/s11368-018-2041-0

Grime JP (2001) Plant strategies, vegetation processes, and ecosystem properties, 2nd edn. Wiley, New York. https://doi.org/10.1016/ S0168-9452(01)00469-1

Hastings A, Byers JE, Crooks JA et al (2007) Ecosystem engineering in space and time. Ecol Lett 10:153-164. https://doi.org/10.1111/j. 1461-0248.2006.00997.x

Hawkes CV et al (2006) Arbuscular mycorrhizal assemblages in native plant roots change in the presence of exotic grasses. Plant Soil 281:369-380. https://doi.org/10.1007/s11104-005-4826-3

Hobbs RJ, Cramer V (2008) Restoration ecology: interventionist approaches for restoring and maintaining ecosystem function in the face of rapid environmental change. Annu Rev Environ Resour 33:39-61. https://doi.org/10.1146/annurev.environ.33. 020107.113631

Holmes PM, Richardson DM, Esler KJ, Witkowski, ETF, Fourie S (2005) A decision-making framework for restoring riparian zones degraded by invasive alien plants in South Africa. S Afr J Sci 101:153. http://hdl.handle.net/11427/24115

Hood WG, Naiman RJ (2000) Vulnerability of riparian zones to invasion by exotic vascular plants. Plant Ecol 148:105-114. https:// doi.org/10.1023/A:1009800327334

Huangfu C, Li K (2019) Growing density interacts with competitor identity to modulate nitrogen form preference of an invasive plant. Ecol Ind 107:105641. https://doi.org/10.1016/j.ecolind. 2019.105641

Hulme PE (2012) Invasive species unchecked by climate. Science 335:537-538. https://doi.org/10.1126/science.335.6068.537-b

Hulme PE (2021) Unwelcome exchange: International trade as a direct and indirect driver of biological invasions worldwide. One Earth 4:666. https://doi.org/10.1016/j.oneear.2021.04.015
IPBES (2019a) Global assessment report on biodiversity and ecosystem services of the Intergovernmental Science-Policy Platform on Biodiversity and Ecosystem Services. In: Brondizio ES, Settele J, Díaz S, Ngo HT (eds). IPBES Secretariat, Bonn (ISBN: 978-3-947851-20-1)

IPBES (2019b) Summary for policymakers of the global assessment report on biodiversity and ecosystem services of the Intergovernmental Science-Policy Platform on Biodiversity and Ecosystem Services. In: Diaz S, Settele J et al. (eds). IPBES secretariat, Bonn. https://doi.org/10.5281/zenodo.3553579. Accessed 27th Sept 2020

IPCC (2013) Climate change 2013: the physical science basis. Contribution of Working Group I to the Fifth Assessment Report of the Intergovernmental Panel on Climate Change. In: Stocker TF, Qin D, Plattner GK, Tignor M, Allen SK, Boschung J, Nauels A, Xia Y, Bex V, Midgley PM (eds). Cambridge University Press, Cambridge (ISBN 9781107661820)

IUCN (2017) The IUCN Red List of Threatened Species. International Union for Conservation of Nature (IUCN) Gland, Switzerland

Jackson R, Banner J, Jobbágy E et al (2002) Ecosystem carbon loss with woody plant invasion of grasslands. Nature 418:623-626. https://doi.org/10.1038/nature00910

Jandova K et al (2014) Long term impact of Heracleum mantegazzianum on soil chemical and biological characteristics. Soil Biol Biochem 68:270-278. https://doi.org/10.1016/j.soilbio.2013.10. 014

Kariyawasam CS et al (2021) Potential risks of invasive alien plant species on agriculture under climate change scenarios in Sri Lanka. Curr Res Environ Sust 3:100051. https://doi.org/10.1016/j.ecoli nd.2021.107951

Kennedy T, Naeem S, Howe K et al (2002) Biodiversity as a barrier to ecological invasion. Nature 417:636-638. https://doi.org/10. 1038/nature00776

Kentula ME (1997) A step toward a landscape approach in riparian restoration. Restor Ecol 5:2-3. https://doi.org/10.1111/j.1526100X.1997.00002.x

Koné AW, et al. (2021)·Chromolaena odorata (L.) K\&R (Asteraceae) invasion effects on soil microbial biomass and activities in a forest-savanna mosaic. Catena 207:5619. https://doi.org/10.1016/j. catena.2021.105619

Kong Y et al (2017) Effect of Ageratina adenophora invasion on the composition and diversity of soil microbiome. J Gen Appl Microbiol 63:114-121. https://doi.org/10.2323/jgam.2016.08.002

Kumar M et al (2021) Invasion of Lantana camara and Ageratina adenophora alters the soil physico-chemical characteristics and microbial biomass of chir pine forests in the central Himalaya, India. Catena 207:105624. https://doi.org/10.1016/j.catena.2021. 105624

Kushwaha SPS, Ramakrishnan PS, Tripathi RS (1981) Population dynamics of Eupatorium odoratum in successional environments following slash and burn agriculture. J Appl Ecol 18:529-535. https://doi.org/10.2307/2402414

Lamb D, Erskine PD, Parrotta JA (2005) Restoration of degraded tropical forest landscapes. Science 310:1628. https://doi.org/10.1126/ science. 1111773

Laurance WF et al (2006) Rain forest fragmentation and the proliferation of successional trees. Ecology 87:469. https://doi.org/10. 1890/05-0064

Lazzaro L et al (2014) Soil and plant changing after invasion: the case of Acacia dealbata in a Mediterranean ecosystem. Sci Total Environ 497-498:491-498. https://doi.org/10.1016/j.scitotenv. 2014.08.014

Leclere D, Obersteiner M, Barrett M et al (2020) Bending the curve of terrestrial biodiversity needs an integrated strategy. Nature 585:551-556. https://doi.org/10.1038/s41586-020-2705-y 
Lekberg Y et al (2013) Severe plant invasions can increase mycorrhizal fungal abundance and diversity. ISME J 7:1424-1433. https:// doi.org/10.1038/ismej.2013.41

Lewis SL, Maslin MA (2015) Defining the Anthropocene. Nature 519:171-180. https://doi.org/10.1038/nature14258

$\mathrm{Li} \mathrm{C}$ et al (2015) Indigenous trees restore soil microbial biomass at faster rates than exotic species. Plant Soil 396:151-161. https:// doi.org/10.1007/s11104-015-2570-x

Lizarralde MS (1993) Current status of the introduced beaver (Castor canadensis) population in Tierra-del-Fuego, Argentina. Ambio 22:351-358

Lowe S, Browne M, Boudjela S, De Poorter M (2000) 100 of the World's Worst Invasive Alien Species. The IUCN Invasive Species Specialist Group (ISSG). http://www.issg.org/pdf/publi cations/worst_100/english_100_worst.pdf

MacDougall AS, Turkington R (2005) Are invasive species the drivers or passengers of change in degraded ecosystems? Ecology 86:42-55. https://doi.org/10.1890/04-0669

McElwee P et al (2020) Ensuring a post-COVID economic agenda tackles global biodiversity loss. One Earth. https://doi.org/10. 1016/j.oneear.2020.09.011

McGeoch M, Jetz W (2019) Measure and reduce the harm caused by biological invasions. One Earth 1:171. https://doi.org/10. 1016/j.oneear.2019.10.003

McLeod ML et al (2016) Exotic invasive plants increase productivity, abundance of ammonia-oxidizing bacteria and nitrogen availability in intermountain grasslands. J Ecol 104:994-1002. https://doi.org/10.1111/1365-2745.12584

Melgoza G, Nowak RS, Tausch RJ (1990) Soil water exploitation after fire: competition between Bromus tectorum (cheatgrass) and two native species. Oecologia 83:7-13. https://doi.org/10. 1007/BF00324626

Monela G et al. (2004) Study on the social, economic and environmental impacts of forest landscape restoration in Shinyanga Region, Tanzania, The World Conservation Union, Eastern Africa Regional Office, Nairobi, Kenya. https://www.ser-rrc. org/resource/a-study-on-the-social-economic/

Montoy D, Rogers L, Memmott J (2012) Emerging perspectives in the restoration of biodiversity-based ecosystem services. Trends Ecol Evolut 27:666-672. https://doi.org/10.1016/j.tree. 2012.07.004

Morris KA et al (2016) The invasive annual cheatgrass releases more nitrogen than crested wheatgrass through root exudation and senescence. Oecologia 181:971-983. https://doi.org/10.1007/ s00442-015-3544-7

Ni G, Zhao P, Huang Q et al (2020) Mikania micrantha invasion enhances the carbon $(\mathrm{C})$ transfer from plant to soil and mediates the soil $\mathrm{C}$ utilization through altering microbial community. Sci Total Environ 711:135020. https://doi.org/10.1016/j.scitotenv. 2019.135020

Nkonya E, Mirzabaev A, Von Braun J (2016) Economics of land degradation and improvement: a global assessment for sustainable development. Springer, Cham (ISBN: 978-3-319-19168-3)

Paini DR et al (2016) Global threat to agriculture from invasive species. Proc Natl Acad Sci USA 113:7575-7579. https://doi.org/ 10.1073/pnas.1602205113

Parepa M, Fischer M, Bossdorf O (2013) Environmental variability promotes plant invasion. Nat Commun 4:1604. https://doi.org/ 10.1038 /ncomms 2632

Parrino EL et al (2021) Lockdown policy effects on invasive species: a perspective. Biodiversity. https://doi.org/10.1080/14888386. 2021.1919554

Pasha SV, Behera MD, Mahawar SK, Barik SK, Joshi SR (2020) Assessment of shifting cultivation fallows in Northeastern India using Landsat imageries. Tropical Ecol 61:65-75. https://doi.org/ 10.1007/s42965-020-00062-0
Pathak HN et al (2021) Impacts of invasive alien plants on ecosystem services of Ramsar lake cluster in middle mountain Nepal. Global Ecol Conserv 27:e01597. https://doi.org/10.1016/j.gecco. 2021.e01597

Pattison Z, Minderman J, Boon PJ, Willby N (2017) Twenty years of change in riverside vegetation: what role have invasive alien plants played? Appl Veg Sci 20:422-434. https://doi.org/10. 1111/avsc. 12297

Paulvon G et al. (2019) Experiences from the South African land degradation neutrality target setting process. Environ Sci Policy 101:54-62. https://doi.org/10.1016/j.envsci.2019.07.003 (Get rights and content)

Pejchar L, Mooney HA (2009) Invasive species, ecosystem services, and human well-being. Trends Ecol Evol 24:497-504. https:// doi.org/10.1016/j.tree.2009.03.016

Pelegrín M, Saez-Tovar JA, Andreu-Rodriguez J et al (2018) Composting of the invasive species Arundo donax with sewage and agrifood sludge: Agronomic, economic and environmental aspects. Waste Manage 78:730-740. https://doi.org/10.1016/j.wasman. 2018.06.029

Pieterse PJ, Boucher C (1997) Is burning a standing population of invasive legumes a viable control method? Effects of a wildfire on an Acacia mearnsii population. S Afr for J 180:15-21. https:// doi.org/10.1080/10295925.1997.9631163

Pimentel D, Zuniga R, Morrison D (2005) Update on the environmental and economic costs associated with alien-invasive species in the United States. Ecol Econ 52:273-288. https://doi.org/10.1016/j. ecolecon.2004.10.002

Pinzone P et al (2018) Do novel weapons that degrade mycorrhizal mutualisms promote species invasion? Plant Ecol 219:539-548. https://doi.org/10.1007/s11258-018-0816-4

Plaza PI, Speziale KI, Lambertucci SA (2018) Rubbish dumps as invasive plant epicentres. Biol Invasions 20(9):2277-2283. https:// doi.org/10.1007/s10530-018-1708-1

Prach K et al. (2007) In linking restoration and ecological succession. In: Walker LR, Hobbs R (eds). Springer, New York, pp 121-149 (eBook ISBN 978-0-387-35303-6)

Prescott-Allen R, Prescott-Allen E (1990) How many plants feed the world? Conserv Biol 4:365-374. https://doi.org/10.1111/j.15231739.1990.tb00310.x

Priyadarshini P, Abhilash PC (2020) Fostering sustainable land restoration through circular economy-governed transitions. Restor Ecol 28:719-723. https://doi.org/10.1111/rec.13181

Pyšek P, Hulme PE, Simberloff D et al (2020) Scientists' warning on invasive alien species. Biol Rev 95:1511-1534. https://doi.org/ $10.1111 /$ brv. 12627

Qu T et al (2021) Invasive species allelopathy decreases plant growth and soil microbial activity. PLoS One 16:e246685. https://doi. org/10.1371/journal.pone.0246685

Rai PK (2009) Comparative assessment of soil properties after Bamboo flowering and death in a tropical forest of Indo-Burma hot spot. Ambio 38(2):118-120. https://doi.org/10.1579/0044-7447-38.2. 118

Rai PK (2012) Assessment of multifaceted environmental issues and model development of an indo-Burma hot spot region. Environ Monit Assess 184:113-131. https://doi.org/10.1007/ s10661-011-1951-8

Rai PK (2013) Plant invasion ecology: impacts and sustainable management. Nova Science Publisher, New York

Rai PK (2015) Paradigm of plant invasion: multifaceted review on sustainable management. Environ Monitor Assess 187:759. https:// doi.org/10.1007/s10661-015-4934-3

Rai PK (2017a) Ethnobotany of other useful plants in North East India: An Indo Burma hot spot region Ethnobotany of India volume 3 North East India and Andaman and Nicobar Island. 
CRC Press (Apple Academic Press), Boca Raton (eBook ISBN9781315365831)

Rai PK (2017b). Ethnoagriculture in North East India: Pros, Cons and eco-sustainable model. In: Ethnobotany of India volume 3 North East India and Andaman and Nicobar Island. CRC Press (Apple Academic Press), Boca Ratin (eBook ISBN9781315365831)

Rai PK (2019) Heavy metals/metalloids remediation from wastewater using free floating macrophytes of a natural wetland. Environ Technol Innov 15:103. https://doi.org/10.1016/j.eti.2019.100393

Rai PK (2021) Heavy metals and arsenic phytoremediation potential of invasive alien wetland plants Phragmites karka and Arundo donax: Water-Energy-Food (WE- F) Nexus linked sustainability implications Bioresour Technol Rep 15:100741. https://doi.org/ 10.1016/j.biteb.2021.100741

Ramakrishnan PS (1993) Shifting agriculture and Sustainable development: an interdisciplinary study from North-East India. Oxford University Press, Oxford (ISBN: 192-3-102749-2)

Ramakrishnan PS (2017) Understanding the impact of invasive Mikania micrantha in shifting agriculture and its management through traditional ecological knowledge. In: Ellison CA, Sankaran KV, Murphy ST (eds) Invasive alien plants. https://www.cabi.org/ environmentalimpact/ebook/20173322108

Ramakrishnan PS (2001) Ecology and sustainable development. National Book Trust, New Delhi

Raman TRS (2001) Effect of slash-and-burn shifting cultivation on rainforest birds in Mizoram, northeast India. Conserv Biol 15:685-698. https://doi.org/10.1046/j.1523-1739.2001.01500 3685.x

Rai PK, Kim KH (2020) Invasive alien plants and environmental remediation: a new paradigm for sustainable restoration ecology. Restor Ecol 28:3-7. https://doi.org/10.1111/rec.13058

Rai PK, Lalramnghinghlova H (2011a) Threatened and less known ethnomedicinal plants of an Indo-Burma hotspot region: conservation implications. Environ Monit Assess 178:53-62. https:// doi.org/10.1007/s10661-010-1670-6

Rai PK, Lalramnghinghlova H (2011b) Ethnomedicinal plants of India with special reference to an Indo-Burma hotspot region: an overview. Ethnobotany Res Appl 9:379-420. https://doi.org/ 10.17348/era.9.0.379-420.

Rai PK, Singh MM (2015) Lantana camara invasion in urban forests of an IndoeBurma hotspot region and its ecosustainable management implication through biomonitoring of particulate matter. J Asia Pac Biodiv 8:375-381. https://doi.org/10.1016/j.japb.2015. 09.003

Rai PK, Singh MM (2020a) Fe- wetland plant's chemical ecology of a Ramsar Site in an Indo-Burma hotspot: in-situ bio-accumulation and phytoremediation implications. Nat Environ Pollut Technol 19:1607-1615. https://doi.org/10.46488/NEPT.2020.v19i04.028

Rai PK, Singh JS (2020b) Invasive alien plant species: their impact on environment, ecosystem services and human health. Ecol Ind 111:106020. https://doi.org/10.1016/j.ecolind.2019.106020

Rai PK, Singh JS (2021) Plant invasion in protected areas, the Indian Himalayan region, and the North East India: progress and prospects. Proc Ind Nat Sci Acad 87:19-35. https://doi.org/10.1007/ s43538-021-00013-w

Rai PK et al (2018) Nanoparticle-plant interaction: implications in energy, the environment, and agriculture. Environ Int 119:1-19. https://doi.org/10.1016/j.envint.2018.06.012

Rai PK, Lee SS, Zhang MM, Tsang YF, Kim KH (2019) Heavy metals in food crops: health risks, fate, mechanisms, and management. Environ Int 125:365-385. https://doi.org/10.1016/j.envint.2019. 01.067

Rai PK, Kim KH, Lee SS, Lee JH (2020) Molecular mechanisms in phytoremediation of environmental contaminants and prospects of engineered transgenic plants/microbes. Sci Total Environ 705:135858. https://doi.org/10.1016/j.scitotenv.2019.135858
Rai PK, Lee S, Brown J, Kim KH (2021) Environmental fate, ecotoxicity biomarkers, and potential health effects of micro- and nano-scale plastic contamination. J Hazard Mater 403:123910. https://doi.org/10.1016/j.jhazmat.2020.123910

Raizada P, Raghubanshi AS, Singh JS (2008) Impacts of invasive alien plant species on soil processes: a review. Proc Natl Acad Sci Ind Biol Sci 78:288-298

Rathee $\mathrm{S}$ et al (2021) Biomass allocation and phenotypic plasticity are key elements of successful invasion of Parthenium hysterophorus at high elevation. Environ Exp Bot 184:104392. https:// doi.org/10.1016/j.envexpbot.2021.104392

Ravi S, D'Odorico P (2008) Post-fire resource redistribution and fertility island dynamics in shrub encroached desert grasslands: a modelling approach. Landsc Ecol 24:325-335. https://doi.org/ $10.1007 / \mathrm{s} 10980-008-9307-7$

Ravi S, D’Odorico P, Herbert B, Zobeck TM, Over TM (2006) Enhancement of wind erosion by fire-induced water repellency. Water Resour Res 42:W11422. https://doi.org/10.1029/ 2006WR004895

Ravi S, D'Odorico P, Collins SL, Huxman TE (2009) Can biological invasions induce desertification? New Phytol 181:512-515. https://doi.org/10.1111/j.1469-8137.2009.02736.x

Ravit B, Ehrenfeld JG, Haggblom MM (2003) A comparison of sediment microbial communities associated with Phragmites australis and Spartina alterniflora in two brackish wetlands of New Jersey. Estuaries 26:465-474. https://doi.org/10.1007/ BF02823723

Reid AM et al (2009) Does invasive plant management aid the restoration of natural ecosystems? Biol Conserv 142L:2342-2349. https://doi.org/10.1016/j.biocon.2009.05.011

Reynolds JL (2021) Earth system interventions as technologies of the Anthropocene. Environ Innov Soc Transit 40:132-146. https:// doi.org/10.1016/j.eist.2021.06.010

Richardson DM, Pyšek P, Rejmánek M et al (2000) Naturalization and invasion of alien plants: concepts and definitions. Divers Distrib 6:93-107. https://doi.org/10.1046/j.1472-4642.2000.00083.x

Richardson DM et al (2007) Riparian vegetation: degradation, alien plant invasions, and restoration prospects. Divers Distrib 13:126139. https://doi.org/10.1111/j.1366-9516.2006.00314.x

Roberts KJ, Anderson RC (2001) Effect of garlic mustard [Alliaria petiolata (Beib.Cavara and Grande)] extracts on plants and arbuscular mycorrhizal (AM) fungi. Am Midl Nat 146:146-152. https:// www.jstor.org/stable/3083161

Rouifed S et al (2012) Invasive knotweeds are highly tolerant to salt stress. Environ Manage 50:1027-1034. https://doi.org/10.1007/ s00267-012-9934-2

Roy M et al (2019) Plant functional traits as indicator of the ecological condition of wetlands in the Grassland and Parkland of Alberta, Canada. Ecol Ind 98:483-491. https://doi.org/10.1016/j.ecolind. 2018.11.021

Sakachep ZK, Rai PK (2021) Influence of invasive alien plants on vegetation of Hailakandi district, Assam, North-East, India. Ind J Ecol 48:261-266

Sala OE, Chapin FS III, Armesto JJ et al (2000) Global biodiversity scenarios for the year 2100. Science 287:1770-1774. https://doi. org/10.1126/science.287.5459.1770

Sampaio B, Holl KD, Scariot A (2007) Does restoration enhance regeneration of seasonal deciduous forests in pastures in central Brazil? Restor Ecol 15:462. https://doi.org/10.1111/j.1526-100X. 2007.00242.x

Saxena KG, Ramakrishnan PS (1983) Growth resource allocation pattern and nutritional status of some dominant annual weeds of slash and burn agriculture (jhum) in northeastern India. Acta Oecol 4:323-333. https://agris.fao.org/agris-search/search.do? recordID $=$ US201302134724 
Schlesinger WH et al (1990) Biological feedbacks in global desertification. Science 147:1043-1048. https://doi.org/10.1126/scien ce. 247.4946 .1043

Schmitz DC et al. (1997) The ecological impact of nonindigenous plants. In: Simberloff $\mathrm{D}$ et al. (eds) Strangers in paradise. Island Press, pp 39-61

Shackleton RT, Shackleton CM, Kull CA (2019) The role of invasive alien species in shaping local livelihoods and human well-being: a review. J Environ Manage 229:145-157. https://doi.org/10. 1016/j.jenvman.2018.05.007

Shiferaw W et al (2021) Invasion of Prosopis juliflora and its effects on soil physicochemical properties in Afar region, Northeast Ethiopia. Int Soil Water Conserv Res. https://doi.org/10.1016/j.iswcr. 2021.04.003 (in press)

Singh MM, Rai PK (2016) Microcosm investigation of Fe (iron) removal using macrophytes of Ramsar Lake: a phytoremediation approach. Int J Phytoremediation 18:1231-1236. https://doi. org/10.1080/15226514.2016.1193471

Smith J, Samways MJ, Taylor S (2007) Assessing riparian quality using two complementary sets of bioindicators. Biodivers Conserv 16:2695-2713. https://doi.org/10.1007/s10531-006-9081-2

Souza AO et al (2018) Local ecological knowledge concerning the invasion of Amerindian lands in the northern Brazilian Amazon by Acacia mangium (Willd.). J Ethnobiol Ethnomed 14:33. https://doi.org/10.1186/s13002-018-0231-x

Stanek M et al (2020) Invasive red oak (Quercus rubra L.) modifies soil physicochemical properties and forest understory vegetation. For Ecol Manage 472:118253. https://doi.org/10.1016/j.foreco. 2020.118253

Stefanowicz AM et al (2018) Differential influence of four invasive plant species on soil physicochemical properties in a pot experiment. J Soils Sediments 18:1409-1423. https://doi.org/10.1007/ s11368-017-1873-3

Stefanowicz AM et al (2019) Invasive plant species identity affects soil microbial communities in a mesocosm experiment. Appl Soil Ecol 136:168-177. https://doi.org/10.1016/j.apsoil.2019.01.004

Swaminathan MS (2003) Bio-diversity: an effective safety net against environmental pollution. Environ Pollut 126:287-291. https:// doi.org/10.1016/S0269-7491(03)00241-0

Swamy PS, Ramakrishnan PS (1987) Contribution of Mikania micrantha during secondary succession following slash and burn agriculture (jhum) in North East India-II nutrient cycling. For Ecol Manage 22:239-249. https://doi.org/10.1016/0378-1127(87) 90108-3

Syed S et al (2021) Invasive Spartina alterniflora in controlled cultivation: environmental implications of converging future technologies. Ecol Ind 130:108027. https://doi.org/10.1016/j.ecoli nd.2021.108027

Toky OP, Ramakrishnan PS (1983) Secondary succession following slash and burn agriculture in north-eastern India. I. Biomass, litterfall and productivity. J Ecol 71:737-745. https://doi.org/10. 2307/2259589

Uddin Md, Robinson RW (2018) Can nutrient enrichment influence the invasion of Phragmites australis? Sci Total Environ 613614:1449-1459. https://doi.org/10.1016/j.scitotenv.2017.06.131

Van der Putten WH, Klironomos Wardle DA (2007) Microbial ecology of biological invasions. ISME J 1:28-37. https://doi.org/10. 1038/ismej.2007.9

Van der Heijden MGA et al (1998) Mycorrhizal fungal diversity determines plant biodiversity, ecosystem variability and productivity. Nature 396:69-72. https://doi.org/10.1038/23932

Vanlalruati Rai PK (2021) The impact of Tithonia diversifolia (Hemsl.) A. Gray on phytosociology and native plants diversity of Aizawl, Mizoram. North East India. Eco Environ Cons 27:S243-S248
Vogelsang K et al. (2004) The use of mycorrhizal fungi in erosion control applications. Final report 65A0070 for Caltrans, California. https://dot.ca.gov/-/media/dot-media/programs/design/docum ents/final-report-65a070-a11y.pdf. Accessed on 15th Apr 2021

Walther $G$ et al (2009) Alien species in a warmer world: risks and opportunities. Trends Ecol Evol 24:686-693. https://doi.org/10. 1016/j.tree.2009.06.008

Wang Y, Lian J, Shen H, Ni Y, Zhang R, Guo Y et al (2020) The effects of Bidens alba invasion on soil bacterial communities across different coastal ecosystem land-use types in southern China. PLoS ONE 15:e0238478. https://doi.org/10.1371/journal.pone. 0238478

Wang J et al (2021) The influence of small-scale resource heterogeneity caused by human activities on the growth phenotype of invasive aquatic plants. Ecol Ind 125:107504. https://doi.org/10.1016/j. ecolind.2021.107504

Waruru M (2018) Over 70\% of Africa's grazing land is facing degradation due to invasive plant species. Down To Earth https:// www.downtoearth.org.in/news/environment/over-70-of-africas-grazing-land-is-facing-degradation-due-to-invasive-plant-speci es-61745 Accessed on 15th Apr 2021

Windham L, Lathrop RG (1999) Effects of Phragmites australis (common reed) invasion on aboveground biomass and soil properties in brackish tidal marsh of the Mullica river, New Jersey. Estuaries 22:927-935. https://doi.org/10.2307/1353072

Wolfe BE, Klironomos JN (2005) Breaking new ground: soil communities and exotic plant invasion. Bioscience 55:477-487. https:// doi.org/10.1641/0006-3568(2005)055[0477:BNGSCA]2.0.CO;2

Woźniak E et al (2021) Bioeconomy development factors in the European Union and Poland. New Biotechnol 60:2-8. https://doi.org/ 10.1016/j.nbt.2020.07.004

Yelenik SG, Stock WD, Richardson DM (2004) Ecosystem level impacts of invasive Acacia saligna in the South African fynbos. Restor Ecol 12:44-51. https://doi.org/10.1111/j.1061-2971.2004. 00289.x

Young AM, Larson BMH (2011) Clarifying debates in invasion biology: a survey of invasion biologists. Environ Res 11:893-898. https://doi.org/10.1016/j.envres.2011.06.006

Young IM et al (1998) The interaction of soil biota and soil structure under global change. Glob Chang Biol 4:703-712. https://doi. org/10.1046/j.1365-2486.1998.00194.x

Yu F et al (2014) Impacts of Ageratina adenophora on soil physicalchemical properties of Eucalyptus plantation and implications for constructing agroforest eco-system. Ecol Eng 64:130-135. https://doi.org/10.1016/j.ecoleng.2013.12.050

Zavaleta E (2000) The economic value of controlling an invasive shrub. Ambio 29:462-467. https://doi.org/10.1579/0044-7447-29.8.462

Zavaleta ES, Hobbs RJ, Mooney HA (2001) Viewing invasive species removal in a whole-ecosystem context. Trends Ecol Evol 16:454-460. https://doi.org/10.1016/S0169-5347(01)02194-2

Zavaleta ES, Shaw MR, Chiariello NR, Mooney HA, Field CB (2003) Additive effects of simulated climate changes, elevated $\mathrm{CO}_{2}$, and nitrogen deposition on grassland diversity. Proc Natl Acad Sci USA 100:7650-7654. https://doi.org/10.1073/pnas.0932734100

Zavaleta-Cortijo C et al (2020) Climate change and COVID-19: reinforcing indigenous food systems. Lancet Planet Health 4:381382. https://doi.org/10.1016/S2542-5196(20)30173-X

Ziska LH et al (2011) Invasive species and climate change: an agronomic perspective. Clim Change 105:13-42. https://doi.org/10. 1007/s10584-010-9879-5 